\title{
Amidation of Esters with Amino Alcohols using Organobase Catalysis
}

Nicola Caldwell,' Peter S. Campbell, 'Craig Jamieson,," Frances Potjewyd," Iain Simpson and Allan J.

B. Watson.'

'Department of Pure and Applied Chemistry, University of Strathclyde, 295 Cathedral Street,

Glasgow G1 1XL, UK. ${ }^{\ddagger}$ AstraZeneca, Oncology Innovative Medicines, Mereside, Alderley Park, Macclesfield SK10 4TG, UK.

*Email: craig.jamieson@strath.ac.uk

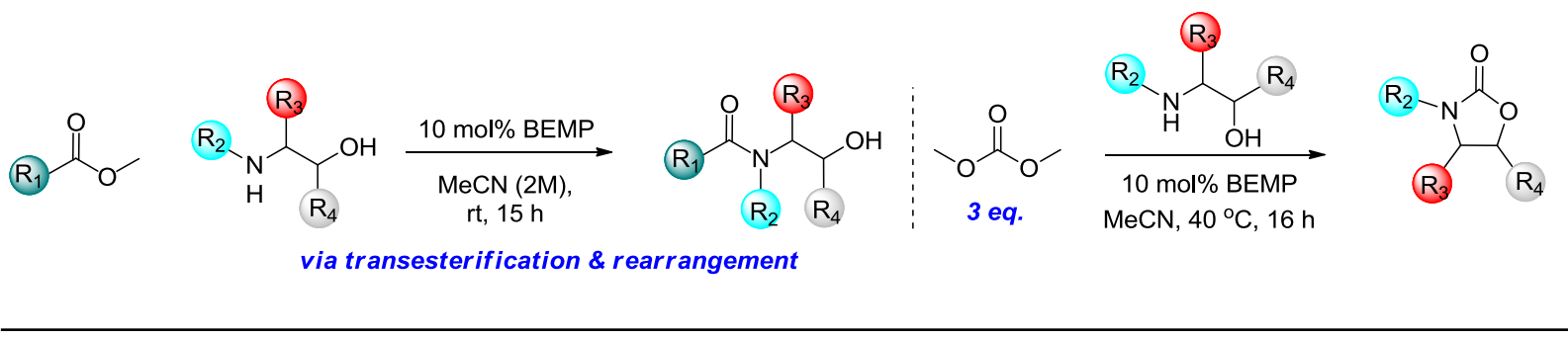

\begin{abstract}
A catalytic protocol for the base-mediated amidation of unactivated esters with amino alcohol derivatives is reported. Investigations into mechanistic aspects of the process indicate the reaction involves an initial transesterification, followed by an intramolecular rearrangement. The reaction is highly general in nature, and can be extended to include the synthesis of oxazolidinone systems through use of dimethyl carbonate.
\end{abstract}

\section{Introduction}

The amide bond is a pivotal functional group from consideration of both chemistry and biology. ${ }^{1,2}$ In an industrial context, formation of the amide bond represents the single largest subset of all reactions conducted in medicinal chemistry laboratories, ${ }^{3,4}$ which further underlines the importance of this ubiquitous functionality. Accordingly, considerable investment has been made in the development of synthetic methodology which enables this transformation in a mild and efficient 
manner, and a broad palette of reagents has now emerged from these efforts. ${ }^{5}$ Having stated this, the majority of reagents currently available to facilitate amide bond formation are stoichiometric in nature, and the poor atom economy associated with their use has prompted calls for their replacement by more efficient and sustainable alternatives. ${ }^{6}$ Given the urgent requirement to address this important issue, a number of catalytic approaches to amide bond formation have emerged in recent years. ${ }^{7}$ For example, these methods include the use of transition metal catalysts, ${ }^{8,9,10}$ boron-derived species, ${ }^{11,12,13}$ or enzymes. ${ }^{14}$ Although many of these catalytic processes have wide utility, they are often associated with some limitations, including use of high temperatures, unsustainable rare earth metals, or extended reaction times.

We recently reported a base-mediated process for the catalytic preparation of amides from esters and amino alcohol derivatives. ${ }^{15}$ Through a combination of reaction screening where we explored a range of organic and inorganic bases and application of Design of Experiments optimization methods, ${ }^{16}$ it was possible to develop a mild, efficient, and unprotracted procedure for the synthesis of amides from unactivated ester derivatives and amino alcohols using a catalytic (10 mol\%) quantity of tert-butylimino-2-diethylamino-1,3-dimethylperhydro-1,3,2-diazaphosphorine $(\text { BEMP, 2) })^{17}$ as a base (Scheme 1). The reaction was posited to proceed through an initial transesterification event mediated by BEMP which liberates an equivalent of alcoxide base capable of catalyzing a further reaction cycle. Rearrangement of the intermediate ester is then thought to lead to the thermodynamically more stable amide product (1). In this study, we present our work in relation to the mechanistic aspects of this base-catalyzed process, as well as a complete report on the scope and limitations of the reaction. Additionally, we demonstrate the applicability of the process to a new reaction manifold enabling the synthesis of oxazolidinone derivatives. 


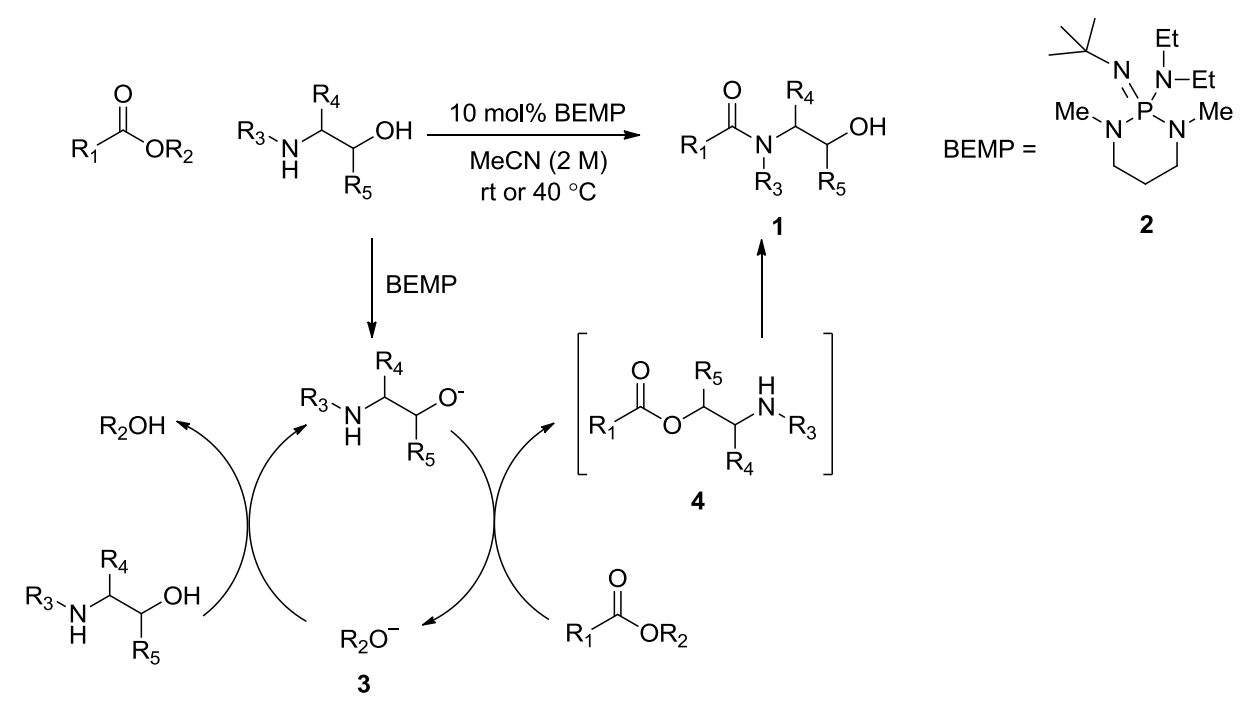

Scheme 1. Organobase-mediated amidation of esters with amino alcohols.

\section{Results and Discussion}

Investigation into reaction mechanism. As intimated in Scheme 1, we reasoned that the reaction proceeds via an initial transesterification process, to yield an intermediate ester represented by 4 . Based on this, we aimed to independently prepare a compound of this type and determine if it was capable of undergoing the requisite rearrangement to the observed amide product. Scheme 2 depicts the preparation of an appropriate test substrate, using a 1,1'-carbonyldiimidazole (CDI) mediated esterification, ${ }^{18}$ followed by acidolysis of the Boc protecting group to yield the salt $\mathbf{6}$. We initially attempted to isolate intermediate ester $\mathbf{6}$ using the conditions established in Scheme 1 (10 mol\% BEMP in $\mathrm{MeCN}$ ), however, this was not successful as presumably the esterification is reversible if rearrangement to the amide cannot take place. Treatment of $\mathbf{6}$ with an organic base then enabled smooth conversion to the desired amide product 7 in high yield (95\%). This result indicated that the intermediate esters represented by 4 (Scheme 1) were competent in rearranging to the amide product. 


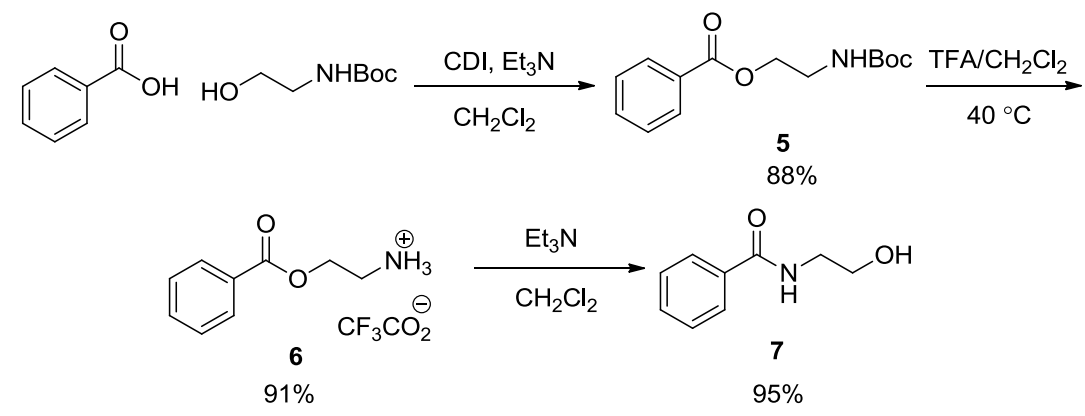

Scheme 2. Preparation of an ester intermediate to probe mechanism.

Previously, we had considered this process to be intramolecular in nature. Accordingly, we designed a series of probe molecules to confirm this proposal, and exclude any potential intermolecular amidation pathways. In the first instance, we conducted a competition experiment, condensing ethanolamine and propylamine with methyl phenylacetate (Scheme 3). In this case, the exclusive product obtained was ethanolamine-derived amide $\mathbf{8}$ in high yield, supporting the view that a more favourable transesterification and subsequent intramolecular rearrangement was operative.

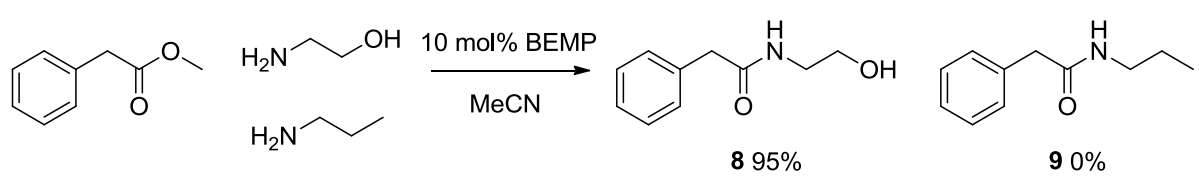

Scheme 3. Competition experiment.

With this information in hand, we then designed a series of probe molecules which could offer additional support to the notion of an intramolecular rearrangement. Accordingly, we examined the effect of homologation of the amino alcohol partner on reaction yield (Figure 1). Increasing the chain length would be anticipated to have a deleterious effect on conversion due to the increased flexibility of the system, which then disfavours the required rearrangement of the proposed intermediate ester to the target amide. Additionally, when increasing the chain length of the amino alcohols, the cyclic transition states arising from the proposed intramolecular rearrangement increase from a five membered ring with ethanolamine, through to an eight membered ring with pentanolamine. The strain associated with the differing cycle sizes are calculated as follows: five 
membered, $6 \mathrm{kcal} / \mathrm{mol}$; six membered, $0.1 \mathrm{kcal} / \mathrm{mol}$; seven membered, $6.2 \mathrm{kcal} / \mathrm{mol}$; eight membered, $9.7 \mathrm{kcal} / \mathrm{mol} .{ }^{19}$ From consideration of this aspect of the reaction, it can again be reasoned that longer chain amino alcohols should be less competent substrates. If an intermolecular process leading to a direct amidation was applicable, then it could be anticipated that the reaction yield would not be significantly affected by homologation over the range examined in the current study. Consideration of a range of products with increasing chain length $(\mathbf{8}, \mathbf{1 0 a}-\mathbf{c}$, Figure 1) under the standard conditions outlined in Scheme 1 confirms this to be the case; extending the chain length to the butanolamine analogue 10b results in a significant erosion in yield compared to 10a, with the pentanolamine system 10c completely failing to form. The effect of the acidic $\mathrm{pKa}$ of the alcohol moiety is not believed to influence the observed yield; if an increase in acidic pKa was noted then it would disfavour initial deprotonation and retard the overall process. Consideration of the relevant $\mathrm{pKa}$ values for propanolamine, butanolamine and pentanolamine are all around $15,{ }^{20}$ indicating the differences in reactivity observed in homologating the amino alcohol species are unlikely to be attributable to changes in pKa. These results lend further credence to the initial hypothesis of an intramolecular rearrangement following transesterification.

We next examined a further set of substrates (10d-f, Figure 1) which could provide additional evidence in support of our proposed mechanism. The 4-hydroxypiperidine amide 10d is a conformationally locked analogue of the propanolamine derivative 10a and was thus anticipated to be too constrained to undergo rearrangement to the amide following transesterification, which is consistent with the conversion observed in this case. Additionally, the benzylamine-derived product 10e is not an effective substrate from both enthalpic and entropic considerations. An analogous amide product 10f was successfully isolated, albeit in reduced yield in comparison to aliphatic-based progenitors, indicating the tolerance of phenols as substrates. By contrast, however, the isomeric amide system $10 \mathrm{~g}$ did not form under the standard conditions developed, presumably due to the lower nucleophilicity of the aniline in the context of the ester rearrangement, which indicates a potential limitation of the current approach with this class of substrate. 

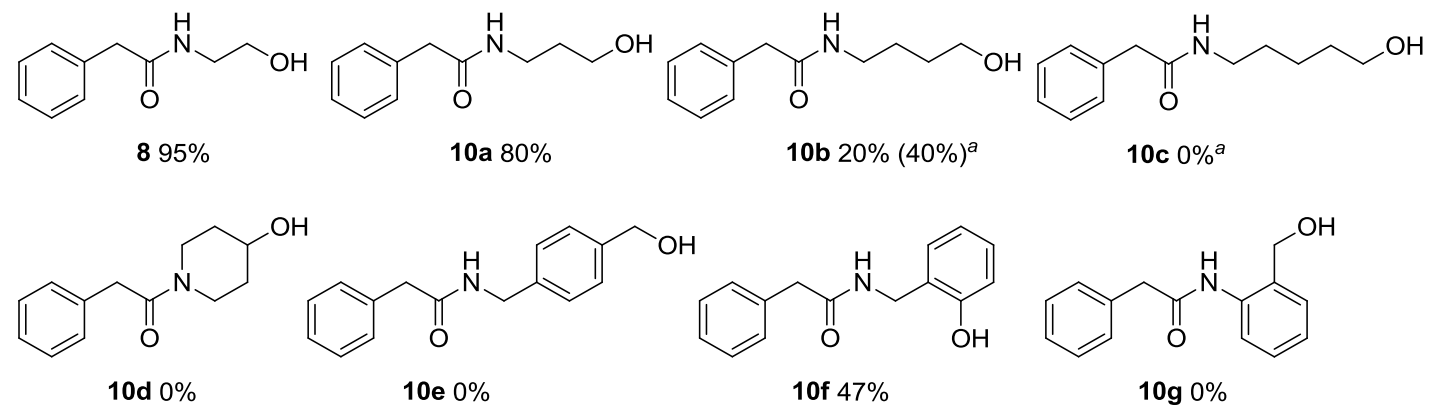

Figure 1. Mechanistic probes evaluated. (a) Reaction performed at $40{ }^{\circ} \mathrm{C}$.

In the last part of this aspect of the study, we sought to establish relative rates of conversion between a secondary amine in comparison with a primary amine, and upon comparing an amino diol with an amino alcohol. Compounds 11a and 11b (Figure 2) could be isolated in excellent yields (91 and $88 \%$, respectively) using the existing protocol and these were used together with compound $\mathbf{8}$ to assess conversion to each product as a function of time. The data which emerged from this experiment indicated rapid conversion to product in each case and in a relatively short timeframe (less than one hour). There was little difference between any of the substrates in terms of their rates of conversion, with the amino diol 11b exhibiting a marginally faster temporal profile. No evidence for the corresponding ester intermediates could be detected in the HPLC assay, suggesting this is potentially the rate determining step and rearrangement to amide product is extremely rapid in each case.

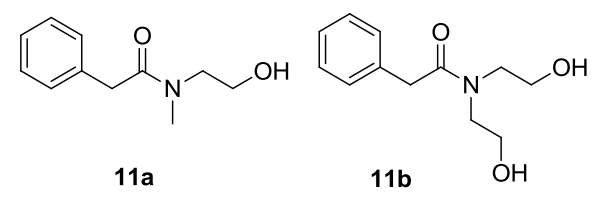




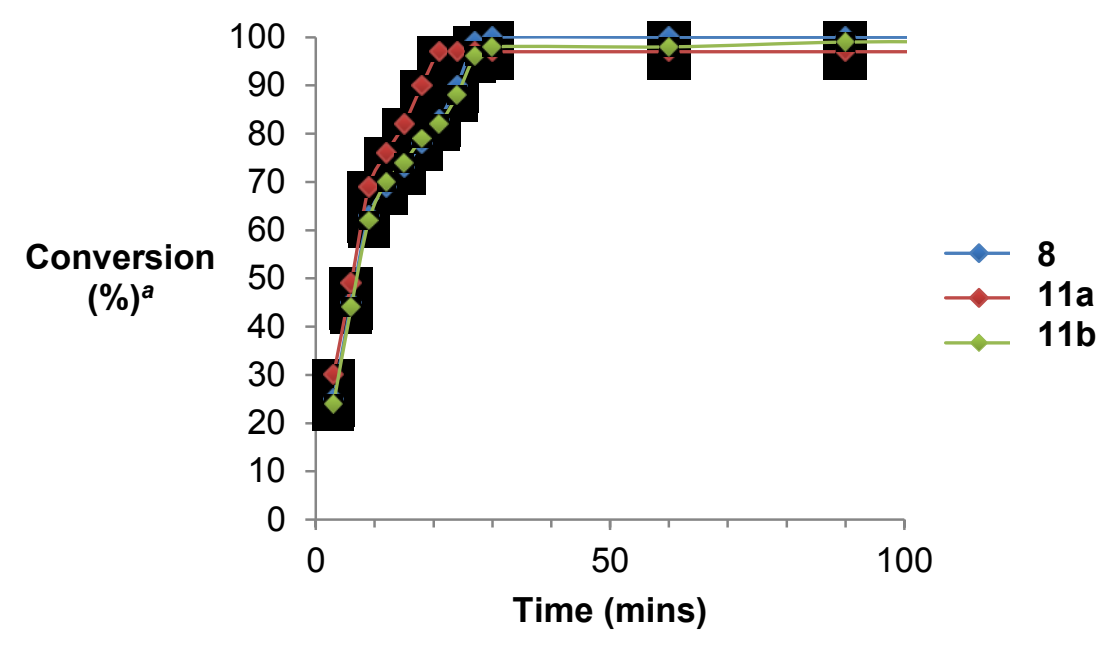

Figure 2. Assessment of conversion as a function of time. (a) Determined by HPLC using an internal standard.

Scope of the amidation process. In the second part of this study, we aimed to more fully delineate the scope of the reaction. In order to evaluate this, a broad range of ester derivatives and amino alcohols were examined using the established reaction conditions $(10 \mathrm{~mol} \% \mathrm{BEMP}, \mathrm{MeCN}$, room temperature or $40{ }^{\circ} \mathrm{C}, 15 \mathrm{~h}$ ), and the results of this survey are presented in Figure 3. Various substituted benzamide systems (12a-e) can be readily accessed and in good to excellent yield. Again, where yields are lower at room temperature, application of modest heating (12b) is effective in furnishing high yields. Aliphatic ester derivatives (12f-h) also perform well in the reaction which is useful for the synthesis of lead-like compounds ${ }^{21}$ in a discovery chemistry setting exemplified by $\mathbf{1 2} \mathbf{g}$ and $\mathbf{1 2 h}$. In relation to this, the synthesis of heterocyclic amide derivatives is an important objective in a medicinal chemistry effort, ${ }^{22}$ therefore evaluation of the current methodology using such substrates is warranted. Accordingly, a raft of different heterocyclic motifs exemplified by compounds 12i-t were examined. Pyridine (12i, 12l), pyrimidine $(\mathbf{1 2 k}, \mathbf{1 2} \mathbf{p})$, pyrazine $(\mathbf{1 2 j})$, pyrrole $(\mathbf{1 2 0})$, thiophene (12q) and furan (12r) all perform well along with saturated heterocyclic motifs such as $12 \mathrm{~s}$ and leadlike architectures such as $\mathbf{1 2 t}$. Focusing on the triazole-derived motifs, compound $\mathbf{1 2} \mathbf{m}$ was isolated in a low yield of $28 \%$. However, we attribute this to the poor solubility of both the ester starting material and product itself in the reaction solvent. By contrast, the corresponding methylated analogue 
12n is completely soluble in the reaction milieu, which is reflected in the excellent yield (94\%) obtained with this compound.

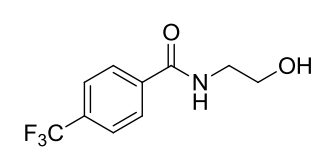

12a $95 \%$<smiles>O=C(CC1CCCCC1)NCCO</smiles>

$12 f 100 \%$<smiles>Cc1cc(C(=O)NCCCO)nc(Cl)n1</smiles>

$12 k 80 \%$<smiles>O=C(NCCO)c1ncccn1</smiles>

12 p $82 \%$<smiles>Cc1ccccc1C(=O)NCCO</smiles>

12b $60 \%(94 \%)^{a}$<smiles>O=C(NCCO)C1CCN(Cc2ccccc2)CC1</smiles>

$\operatorname{l2g} 66 \%$<smiles>Cc1ccc(C(=O)NCCCO)cn1</smiles>

12I $75 \%$<smiles>O=C(NCCO)c1cccs1</smiles>

12q $99 \%$<smiles>COc1ccc(C(=O)NCCO)cc1</smiles>

12c $82 \%$<smiles>N#Cc1cccc(OC(C(=O)NCCO)c2cccc3ccccc23)c1</smiles>

12h $61 \%$<smiles>O=C(NCCO)c1nnc[nH]1</smiles>

$12 \mathrm{~m} 28 \%$<smiles>O=C(NCCO)c1ccco1</smiles>

12r $94 \%$<smiles>O=C(CCO)c1cccc(Br)c1</smiles>

12d 99\%<smiles>O=C(NCCCO)c1cccnc1</smiles>

12i $89 \%$<smiles>Cn1ncnc1C(=O)NCCO</smiles>

12n $94 \%$<smiles>COC1CCC(C(=O)NCCO)N1</smiles>

12s $61 \%$<smiles>O=C(NCCO)c1ccccc1Br</smiles>

12e $96 \%$<smiles>O=C(NCCO)c1cnccn1</smiles>

12j $68 \%$<smiles>O=C(NCCO)c1ccc[nH]1</smiles>

$12092 \%$<smiles>Cc1noc(-c2ccc(Br)cc2)c1C(=O)NCCO</smiles>

12t, $66 \%$

Figure 3. Scope of amide synthesis with straight chain amino alcohols.

Additionally, to enable a direct comparison between the current catalytic approach and existing stoichiometric methods, we independently prepared the pyrimidine derivative $\mathbf{1 2 p}$ using $N, N, N^{\prime}, N^{n}$-tetramethyl-O-(1H-benzotriazol-1-yl)uroniumhexafluorophosphate (HATU) ${ }^{23}$ as a coupling agent with the corresponding carboxylic acid (Scheme 4). Pleasingly, the catalytic approach described here performs well in comparison to a standard coupling reagent, furnishing $\mathbf{1 2} \mathbf{p}$ in a slightly improved yield over the existing method, with the clear advantage of obviating the need for stoichiometric reagents and generation of associated by-products

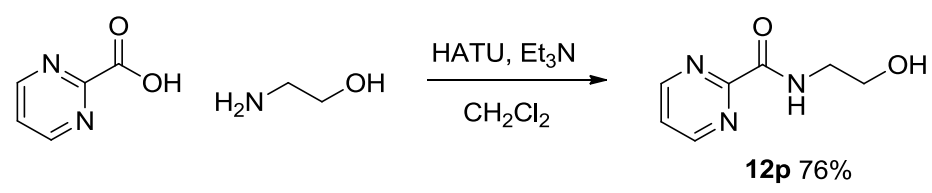

Scheme 4. Comparative synthesis of $\mathbf{1 2 b}$ with stoichiometric reagents. 
In addition to the straight-chain amino alcohol systems discussed above, we also examined further range of substrates as outlined in Figure 4. (S)-Prolinol proved to be an effective nucleophile with benzoate esters (13a), cinnamate derivatives (13b), heterocyclic systems (13c, 13d) as well as alkyl esters (13e). Amide 13a was also prepared from methyl 4-bromo-2-chlorobenzoate and (S)prolinol on a $2.5 \mathrm{~g}$ scale in excellent yield, which serves to demonstrate the utility of the method for larger scale synthesis. Other amino alcohols derived from proteinogenic amino acids such as phenylalaninol were also competent substrates in the reaction (13f) allowing access to peptidic structures. Further evaluation of secondary amine derivatives as nucleophiles showed that these to be robust substrates as exemplified by compounds $13 \mathrm{~g}$ and $\mathbf{1 3 h}$. As discussed above, amino diols performed well in the reaction and amide 13i is a further example of this substrate class. Secondary and tertiary alcohols represent a more significant challenge which can be ascribed to a more demanding initial transesterification reaction. Having stated this, application of modest heating enabled the isolation of $\mathbf{1 3} \mathbf{j}$ in good yield using our catalytic process. In the case of tertiary alcohols, we could not prepare amides from electron-neutral substrates such as methyl phenylacetate (leading to 13k), suggesting a possible limitation of the methodology. However, when more electron withdrawing esters are employed, the corresponding products such as $\mathbf{1 3 I}$ can be isolated in preparatively useful yield. It was not possible to identify any ester intermediate in the reaction to form $\mathbf{1 3 I}$ indicating rapid rearrangement to the thermodynamically favourable amide, as noted previously. 


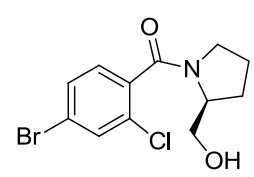

13a $93 \%(92 \%)^{a}$

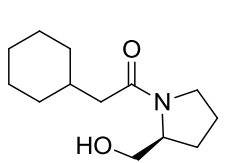

13e $40 \%(75 \%)^{b}$<smiles>O=C(Cc1ccccc1)NC(CO)CO</smiles>

$13 \mathbf{i} 81 \%$<smiles>O=C(/C=C/c1ccccc1)N1CCCC1O</smiles>

13b $92 \%$<smiles>O=C(c1cccnc1)N1CCC[C@H]1CO</smiles>

13c $86 \%$<smiles>O=C(Cc1ccccc1)N(CCO)Cc1ccccc1</smiles>

13g $97 \%$<smiles>CC(C)(O)CNC(=O)Cc1ccccc1</smiles>

$13 \mathrm{k} 0 \%$<smiles>O=C(c1ccc2[nH]ccc2c1)N1CCCC1O</smiles>

13d $57 \%$

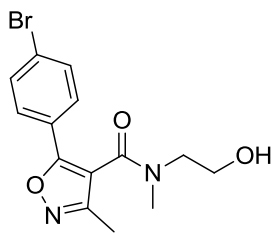

13h $90 \%$<smiles>CC(C)(O)CNC(=O)c1ccc(C(F)(F)F)cc1</smiles>

$13151 \%$

Figure 4. Scope of amino alcohol component. (a) $2.5 \mathrm{~g}$ scale input; (b) performed at $40{ }^{\circ} \mathrm{C}$.

In the concluding part of our study, we turned our attention to application of the methodology to the synthesis of oxazolidinone derivatives. These important heterocyclic motifs are used widely in both asymmetric synthesis ${ }^{24}$ and medicinal chemistry, ${ }^{25}$ therefore a mild and efficient approach to their synthesis would be attractive. Typically, oxazolidinones are synthesized by the reaction of a suitable amino alcohol and diethyl carbonate in the presence of excess base (e.g. $\left.\mathrm{K}_{2} \mathrm{CO}_{3}, \mathrm{NaOMe}\right)$ whilst heating, usually to temperatures in excess of $100{ }^{\circ} \mathrm{C} .{ }^{26}$ Given that we had established that formation of an intermediate ester followed by cyclisation to an amide was taking place in the amidation reaction, it was reasoned that this could be exploited in the synthesis of oxazolidinones. Adapting the reaction conditions outlined above could potentially offer a favourable alternative to the typical synthesis of such compounds, having the advantage of being performed at significantly lower temperatures and through the use of catalytic amounts of base. A brief survey of stoichiometry of the dimethylcarbonate (DMC) starting material was carried out in a model reaction with phenylalaninol (Table 1). Given the low cost and abundance of DMC in relation to the amino alcohol precursors, we elected to use an excess of this reagent. To afford the highest probability of success, we also examined the use of slightly elevated temperatures from the outset. 


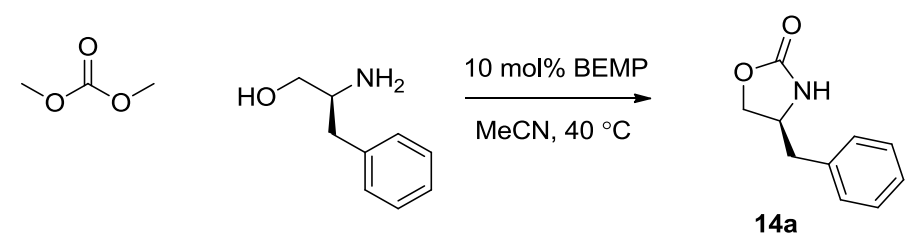

\begin{tabular}{|c|c|c|}
\hline Entry & $\begin{array}{c}\text { Dimethyl carbonate } \\
\text { (equiv.) }\end{array}$ & Conversion (\%) ${ }^{\boldsymbol{a}}$ \\
\hline 1 & 1 & 68 \\
\hline 2 & 3 & 72 \\
\hline 3 & 5 & 69 \\
\hline 4 & 6 (neat) & 61 \\
\hline
\end{tabular}

Table 1. Survey of conditions for oxazolidinone synthesis. (a) Determined by HPLC using an internal standard.

Pleasingly, we observed good levels of conversion to the desired product in each of the reactions attempted. From this short screening exercise, we confirmed that 3 equivalents of the carbonate component was optimal, which provided encouragement to explore the synthesis of a small range of oxazolidinone derivatives using this approach (Figure 5).

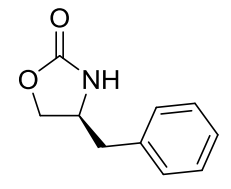

$14 a 68 \%$

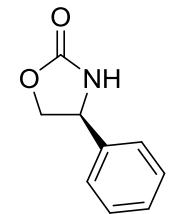

$14 \mathrm{~b} 66 \%$

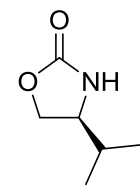

$14 \mathrm{c} 84 \%$<smiles>O=C1NCCO1</smiles><smiles>O=C1OC[C@H]2CCCN12</smiles>

14 e $69 \%$<smiles>O=C1NC(CO)CO1</smiles>

$14 f 87 \%$

Figure 5. Application to the synthesis of oxazolidinone systems.

Considering the focused sub-set outlined in Figure 5, a range of oxazolidinone derivatives could be prepared using an appropriate amino alcohol and dimethyl carbonate under relatively mild conditions using catalytic BEMP, and in generally good yield. Amino alcohols derived from proteinogenic amino acids were very effective in the reaction (14a-c, 14e), while ethanolamine gave acceptable yields of oxazolidin-2-one (14d). Aminodiols were also tolerated in this process, leading to products such as $\mathbf{1 4 f}$ in excellent isolated yield. 


\section{Conclusion}

A mild and efficient synthesis of amide derivatives from esters and amino alcohols has been reported using an organic base as a catalyst. The full scope of the reaction has been evaluated including application towards amide products of potential pharmaceutical relevance and extension of the methodology towards the preparation of the versatile oxazolidinone motif. Additionally, through design and study of appropriate probe molecules, the mechanism of the reaction has been delineated, indicating an initial transesterification is taking place, followed by rapid and facile rearrangement to the corresponding amide products.

\section{Experimental Section}

General Methods. All reagents and solvents were used as obtained unless otherwise stated. Purification was carried out according to standard laboratory methods. ${ }^{27}$ BEMP was purified by vacuum distillation from $\mathrm{CaH}_{2}$ and stored in a septum-sealed oven-dried flask over previously activated $4 \AA$ A molecular sieves and purged with and stored under nitrogen. Reactions were carried out under Schlenk conditions using oven-dried glassware, which was evacuated and purged with $\mathrm{N}_{2}$ before use. Thin layer chromatography was carried out using aluminium-backed silica plates which were analysed under $254 \mathrm{~nm}$ UV light or developed using potassium permanganate solution. Flash chromatography was carried out using prepacked silica cartridges. ${ }^{1} \mathrm{H}$ NMR spectra were recorded at 400 or $500 \mathrm{MHz}$ and ${ }^{13} \mathrm{C}$ NMR spectra were recorded at 101 or $126 \mathrm{MHz}$. Chemical shifts are reported in ppm and coupling constants are reported in $\mathrm{Hz}$ with $\mathrm{CDCl}_{3}$ referenced at $7.27\left({ }^{1} \mathrm{H}\right)$ and $77.23 \mathrm{ppm}\left({ }^{13} \mathrm{C}\right)$, and DMSO referenced at $2.50\left({ }^{1} \mathrm{H}\right)$ and $39.51 \mathrm{ppm}\left({ }^{13} \mathrm{C}\right)$. Mass spectrometry data was generated using a TOF analyser. Optical rotations were measured at $589 \mathrm{~nm}$, with concentrations reported in g per $100 \mathrm{~mL}$. Conversions were determined by HPLC using iodobenzene as an internal standard. The data for products $8,12 \mathrm{a}, 12 \mathrm{~b}, 12 \mathrm{c}, 12 \mathrm{f}, 12 \mathrm{i}, 12 \mathrm{q}, 12 \mathrm{r}, 13 \mathrm{c}, 13 \mathrm{e}, 13 \mathrm{f}$ and $13 \mathrm{j}$ were reported in our earlier communication. ${ }^{15}$

2-((tert-Butoxycarbonyl)amino)ethyl benzoate (5). ${ }^{28}$ To a solution of benzoic acid (341 mg, $2.8 \mathrm{mmol})$ in $\mathrm{CH}_{2} \mathrm{Cl}_{2}(2 \mathrm{~mL})$ was added $\mathrm{CDI}(456 \mathrm{mg}, 3 \mathrm{mmol})$ and $\mathrm{Et}_{3} \mathrm{~N}(418 \mu \mathrm{L}, 3 \mathrm{mmol})$. The 
reaction mixture was stirred at room temperature for $16 \mathrm{~h}$, then washed with water, dried $\left(\mathrm{MgSO}_{4}\right)$, filtered, and concentrated to a residue that was purified by flash column chromatography $(25 \%$ ethyl acetate/petroleum ether) to afford the title compound as a white solid (653 $\mathrm{mg}, 88 \%): v_{\max }$ (neat) $3375,1701,1530 \mathrm{~cm}^{-1} ;{ }^{1} \mathrm{H}$ NMR $\left(500 \mathrm{MHz}, \mathrm{CDCl}_{3}\right): \delta_{\mathrm{H}} 8.07-8.04(\mathrm{~m}, 2 \mathrm{H}), 7.58(\mathrm{tt}, J=7.5,1.5 \mathrm{~Hz}$, 1H), $7.47-7.43(\mathrm{~m}, 2 \mathrm{H}), 4.87$ (br. s, $1 \mathrm{H}), 4.39(\mathrm{t}, J=5.5 \mathrm{~Hz}, 2 \mathrm{H}) ; 3.54(\mathrm{~d}, J=4.5 \mathrm{~Hz}, 2 \mathrm{H}), 1.45(\mathrm{~s}$, $9 \mathrm{H}) ;{ }^{13} \mathrm{C}$ NMR $\left(126 \mathrm{MHz}, \mathrm{CDCl}_{3}\right) \delta_{\mathrm{C}} 166.7,156.0,133.3,130.1,130.0,128.6,79.8,64.5,40.0,28.6$; HRMS (ESI) $m / z$ : [M+Na] $]^{+}$Calcd for $\mathrm{C}_{14} \mathrm{H}_{19} \mathrm{NO}_{4} \mathrm{Na} 288.1204$, Found 288.1204.

2-(Benzoyloxy)ethanaminium 2,2,2-trifluoroacetate (6) To a solution of 2-((tertbutoxycarbonyl)amino)ethyl benzoate $(\mathbf{5}, 398 \mathrm{mg}, 1.5 \mathrm{mmol})$ in $\mathrm{CH}_{2} \mathrm{Cl}_{2}(1 \mathrm{~mL})$ was added trifluoroacetic acid $(1 \mathrm{~mL})$. The reaction mixture was stirred at room temperature for $16 \mathrm{~h}$, heated at $40{ }^{\circ} \mathrm{C}$ for $24 \mathrm{~h}$ then concentrated under vacuum to afford the title compound as a white solid $(381 \mathrm{mg}$, 91\%): $v_{\max }$ (neat) 3330, 3107, 2967, 1725, $1544 \mathrm{~cm}^{-1} ;{ }^{1} \mathrm{H}$ NMR $(500 \mathrm{MHz}, \mathrm{DMSO}) \delta_{\mathrm{H}} 8.09$ (dd, $J=$ 8.2, $1.3 \mathrm{~Hz}, 2 \mathrm{H}), 8.03$ (br. s, 2H), 7.69 (tt, $J=7.3,1.3 \mathrm{~Hz}, 1 \mathrm{H}), 7.57-7.54$ (m, 2H), 4.44 (t, $J=5.8$ $\mathrm{Hz}, 2 \mathrm{H}), 3.25$ (q, $J=4.7 \mathrm{~Hz}, 2 \mathrm{H}), 1 \mathrm{H}$ missing (exchangeable); ${ }^{13} \mathrm{C}$ NMR $(126 \mathrm{MHz}, \mathrm{DMSO}) \delta_{\mathrm{C}}$ 165.6, 133.6, 129.6, 129.3, 128.6, 61.5, 38.0; HRMS (ESI) $m / z$ : [M] $]^{+}$Calcd for $\mathrm{C}_{9} \mathrm{H}_{12} \mathrm{NO}_{2}$ 166.0863, Found 166.0858 .

$\mathrm{N}$-(2-Hydroxyethyl)benzamide (7). ${ }^{15}$ To a solution of 2-aminoethyl benzoate $(\mathbf{6}, 381 \mathrm{mg}, 1.37$ mmol $)$ in $\mathrm{CH}_{2} \mathrm{Cl}_{2}(3 \mathrm{~mL})$ was added $\mathrm{Et}_{3} \mathrm{~N}(226 \mu \mathrm{L}, 1.64 \mathrm{mmol})$. The reaction mixture was stirred at room temperature for 16 hours then concentrated to a residue that was purified by flash column chromatography ( $5 \%$ methanol/ $\mathrm{CH}_{2} \mathrm{Cl}_{2}$ ) to afford the title compound as a white solid (306 $\left.\mathrm{mg}, 95 \%\right)$ : $\mathrm{U}_{\max }$ (neat) 3296, 2937, 2876, 1634, $1537 \mathrm{~cm}^{-1} ;{ }^{1} \mathrm{H}$ NMR $\left(500 \mathrm{MHz}, \mathrm{CDCl}_{3}\right) \delta_{\mathrm{H}} 7.80-7.78(\mathrm{~m}, 2 \mathrm{H})$, $7.51(\mathrm{tt}, J=7.3,1.6 \mathrm{~Hz}, 1 \mathrm{H}), 7.45-7.41(\mathrm{~m}, 2 \mathrm{H}), 6.75$ (br. s, 1H), 3.83 (t, $J=5.0 \mathrm{~Hz}, 2 \mathrm{H}), 3.63$ (q, $J$ $=5.2 \mathrm{~Hz}, 2 \mathrm{H}), 2.16$ (br. s, $1 \mathrm{H}) ;{ }^{13} \mathrm{C} \mathrm{NMR}\left(126 \mathrm{MHz}, \mathrm{CDCl}_{3}\right) \delta_{\mathrm{C}} 168.9,134.3,131.9,128.8,127.2$, 62.6, 43.1; HRMS (ESI) $m / z$ : [M+H] ${ }^{+}$Calcd for $\mathrm{C}_{9} \mathrm{H}_{12} \mathrm{NO}_{2}$ 166.0863, Found 166.0860. 
General Procedure for Base-Catalysed Amide Bond Formation To an oven-dried Schlenk tube containing BEMP $(41 \mu \mathrm{L}, 0.14 \mathrm{mmol})$ and acetonitrile $(700 \mu \mathrm{L})$ was added ester $(1.42 \mathrm{mmol})$ and amino alcohol $(1.42 \mathrm{mmol})$. The reaction mixture was stirred at room temperature or $40{ }^{\circ} \mathrm{C}$ for 15 $\mathrm{h}$ then concentrated to a residue that was purified by flash column chromatography (methanol/ $\mathrm{CH}_{2} \mathrm{Cl}_{2}$ ). For oxazolidinone synthesis, the ester was replaced with dimethyl carbonate $(350 \mu \mathrm{L}, 4.26$ mmol).

$\mathrm{N}$-(3-Hydroxypropyl)-2-phenylacetamide (10a). ${ }^{29}$ White solid (220 $\left.\mathrm{mg}, 80 \%\right): v_{\max }$ (neat) $3310,3242,3067,2945,2882,1655,1564 \mathrm{~cm}^{-1} ;{ }^{1} \mathrm{H}$ NMR (400 MHz, DMSO) $\delta_{\mathrm{H}} 8.01(\mathrm{t}, J=4.4 \mathrm{~Hz}$, 1H), $7.31-7.19(\mathrm{~m}, 5 \mathrm{H}), 4.42(\mathrm{t}, J=4.8 \mathrm{~Hz}, 1 \mathrm{H}), 3.40-3.38(\mathrm{~m}, 4 \mathrm{H}), 3.09$ (q, $J=6.5 \mathrm{~Hz}, 2 \mathrm{H}), 1.54$ (app. quin, $J=6.7 \mathrm{~Hz}, 2 \mathrm{H}) ;{ }^{13} \mathrm{C}$ NMR (101 MHz, DMSO) $\delta_{\mathrm{C}} 170.0,136.6,128.9,128.2,126.3,58.4$, 42.4, 35.8, 32.4; HRMS (ESI) $m / z$ : $[\mathrm{M}+\mathrm{Na}]^{+}$Calcd for $\mathrm{C}_{11} \mathrm{H}_{15} \mathrm{NO}_{2} \mathrm{Na} 216.0995$, Found 216.0991.

N-(4-Hydroxybutyl)-2-phenylacetamide (10b) ${ }^{30}$ White solid (118 mg, 40\%): $\mathrm{v}_{\max }$ (neat) 3358, 3291, 2951, 1636, $1541 \mathrm{~cm}^{-1} ;{ }^{1} \mathrm{H}$ NMR (400 MHz, DMSO) $\delta_{\mathrm{H}} 8.01(\mathrm{t}, J=5.0 \mathrm{~Hz} 1 \mathrm{H}), 7.31-7.18(\mathrm{~m}$, $5 \mathrm{H}), 4.38(\mathrm{t}, \quad J=5.2 \mathrm{~Hz}, 1 \mathrm{H}), 3.39-3.35(\mathrm{~m}, 4 \mathrm{H}), 3.05-3.00(\mathrm{~m}, 2 \mathrm{H}), 1.43-1.37(\mathrm{~m}, 4 \mathrm{H}) ;{ }^{13} \mathrm{C}$ NMR (101 MHz, DMSO) $\delta_{\mathrm{C}} 169.8,136.6,128.9,128.1,126.2,60.4,42.4,38.5,29.8,25.8$; HRMS (ESI) $m / z:[\mathrm{M}+\mathrm{Na}]^{+}$Calcd for $\mathrm{C}_{12} \mathrm{H}_{17} \mathrm{NO}_{2} \mathrm{Na} 230.1152$, Found 230.1146 .

N-(2-Hydroxybenzyl)-2-phenylacetamide (10f). White solid (161 mg, 47\%): $v_{\max }$ (neat) 3279, 3102, 2569, 1626, $1568 \mathrm{~cm}^{-1}$; ${ }^{1} \mathrm{H}$ NMR (400 MHz, $\mathrm{CDCl}_{3}$ ) $\delta_{\mathrm{H}} 9.47$ (br. s, $\left.1 \mathrm{H}\right), 7.41-7.35$ (m, 3H), $7.29-7.25(\mathrm{~m}, 3 \mathrm{H}), 7.10(\mathrm{dd}, J=7.5,1.7 \mathrm{~Hz}, 1 \mathrm{H}), 7.00(\mathrm{dd}, J=8.1,1.0 \mathrm{~Hz}, 1 \mathrm{H}), 6.91-6.86(\mathrm{~m}$, $2 \mathrm{H}), 4.35(\mathrm{~d}, J=6.5 \mathrm{~Hz}, 2 \mathrm{H}), 3.60(\mathrm{~s}, 2 \mathrm{H}) ;{ }^{13} \mathrm{C} \mathrm{NMR}\left(101 \mathrm{MHz}, \mathrm{CDCl}_{3}\right) \delta_{\mathrm{C}} 174.0,156.0,134.0$, $130.9,130.2,129.7,129.3,127.9,124.2,120.0,118.0,43.1,40.9$; HRMS (ESI) $m / z:[\mathrm{M}+\mathrm{H}]^{+}$Calcd for $\mathrm{C}_{15} \mathrm{H}_{16} \mathrm{NO}_{2} 242.1176$, Found 242.1177.

$N$-(2-Hydroxyethyl)-N-methyl-2-phenylacetamide (11a). ${ }^{31}$ Yellow oil (249 mg, 91\%): $\mathrm{v}_{\max }$ (neat) $3339,3129,2900,1641,1500 \mathrm{~cm}^{-1} ;{ }^{1} \mathrm{H} \mathrm{NMR}\left(400 \mathrm{MHz}, \mathrm{CDCl}_{3}\right) \delta_{\mathrm{H}} 7.36-7.30(\mathrm{~m}, 2 \mathrm{H}), 7.28-$ $7.25(\mathrm{~m}, 3 \mathrm{H}), 3.82(\mathrm{~s}, 0.73 \mathrm{H}$, minor rotamer), $3.76-3.73(\mathrm{~m}, 2.47 \mathrm{H}$, major + minor rotamers), $3.65(\mathrm{t}$, $J=5.4 \mathrm{~Hz}, 0.75 \mathrm{H}$, minor rotamer,), 3.55 (t, $1.28 \mathrm{H}, J=5.4 \mathrm{~Hz}$, major rotamer,), 3.43 (t, $J=5.4 \mathrm{~Hz}$, $0.84 \mathrm{H}$, minor rotamer,) 3.32 (br. s, $1 \mathrm{H}), 3.06(\mathrm{~s}, 1.85 \mathrm{H}$, major rotamer), 2.96 (s, $1.10 \mathrm{H}$, minor 
rotamer); ${ }^{13} \mathrm{C} \mathrm{NMR}\left(101 \mathrm{MHz}, \mathrm{CDCl}_{3}\right.$, major rotamer) $\delta_{\mathrm{C}} 172.9,134.7,128.9,128.8,126.9,60.8$, 51.3, 41.1, 37.2; ${ }^{13} \mathrm{C}$ NMR (101 MHz, $\mathrm{CDCl}_{3}$, minor rotamer) $\delta_{\mathrm{C}} 172.3,135.5,129.0,128.6,126.8$, 59.5, 52.4, 40.6, 33.9; HRMS (ESI) $m / z$ : $[\mathrm{M}+\mathrm{H}]^{+}$Calcd for $\mathrm{C}_{11} \mathrm{H}_{16} \mathrm{NO}_{2}$ 194.1176, Found 194.1173.

N,N-Bis(2-hydroxyethyl)-2-phenylacetamide (11b). White solid (279 mg, 88\%): $\mathrm{v}_{\max }$ (neat) 3329, 3204, 2903, 1601, $1479 \mathrm{~cm}^{-1} ;{ }^{1} \mathrm{H}$ NMR (500 MHz, DMSO): $\delta_{\mathrm{H}} 7.31-7.28$ (m, 2H), $7.22-7.20$ (m, 3H), $4.86(\mathrm{t}, J=5.3 \mathrm{~Hz}, 1 \mathrm{H}), 4.65(\mathrm{t}, J=5.3 \mathrm{~Hz}, 1 \mathrm{H}), 3.73(\mathrm{~s}, 2 \mathrm{H}), 3.52(\mathrm{q}, J=5.7 \mathrm{~Hz}, 2 \mathrm{H}), 3.48$ $(\mathrm{q}, J=5.9 \mathrm{~Hz}, 2 \mathrm{H}), 3.43(\mathrm{t}, J=5.8 \mathrm{~Hz}, 2 \mathrm{H}), 3.36(\mathrm{t}, J=6.2 \mathrm{~Hz}, 2 \mathrm{H}) ;{ }^{13} \mathrm{C}$ NMR $(126 \mathrm{MHz}, \mathrm{DMSO}) \delta_{\mathrm{C}}$ 170.6, 136.3, 129.0, 128.2, 126.2, 59.2, 58.8, 50.8, 48.4, 1C missing (coincident); HRMS (ESI) $m / z$ : $[\mathrm{M}+\mathrm{Na}]^{+}$Calcd for $\mathrm{C}_{12} \mathrm{H}_{17} \mathrm{NO}_{3} \mathrm{Na} 246.1101$, Found 246.1099.

3-Bromo-N-(2-hydroxyethyl)benzamide (12d). White solid (343 mg, 99\%): $v_{\max }$ (neat) 3360, $3291,3065,2951,1636,1541 \mathrm{~cm}^{-1} ;{ }^{1} \mathrm{H}$ NMR $(500 \mathrm{MHz}, \mathrm{DMSO}) \delta_{\mathrm{H}} 8.55(\mathrm{t}, J=5.2 \mathrm{~Hz}, 1 \mathrm{H}), 8.04(\mathrm{t}$, $J=1.8 \mathrm{~Hz}, 1 \mathrm{H}), 7.86-7.84(\mathrm{~m}, 1 \mathrm{H}), 7.72(\mathrm{ddd}, J=8.0,2.0,1.0 \mathrm{~Hz}, 1 \mathrm{H}), 7.43(\mathrm{t}, J=7.9 \mathrm{~Hz}, 1 \mathrm{H})$, $3.51(\mathrm{t}, J=6.2 \mathrm{~Hz}, 2 \mathrm{H}), 3.32(\mathrm{q}, J=6.1 \mathrm{~Hz}, 2 \mathrm{H}), 1 \mathrm{H}$ missing (exchangeable); ${ }^{13} \mathrm{C}$ NMR $(126 \mathrm{MHz}$, DMSO) $\delta_{\mathrm{C}} 164.8,136.7,133.8,130.5,129.9,126.3,121.6,59.6,42.3$; HRMS (ESI) $m / z:[\mathrm{M}+\mathrm{Na}]^{+}$ Calcd for $\mathrm{C}_{9} \mathrm{H}_{10} \mathrm{BrNO}_{2} \mathrm{Na} 265.9784$, Found 265.9785.

2-Bromo-N-(2-hydroxyethyl)benzamide (12e). White solid (332 mg, 96\%): $\mathrm{v}_{\max }$ (neat) 3412, $3220,3066,2928,1623,1558 \mathrm{~cm}^{-1} ;{ }^{1} \mathrm{H}$ NMR $\left(400 \mathrm{MHz}, \mathrm{CDCl}_{3}\right) \delta_{\mathrm{H}} 7.57(\mathrm{dd}, J=8.0,1.1 \mathrm{~Hz}, 1 \mathrm{H})$, $7.50(\mathrm{dd}, J=7.6,1.8 \mathrm{~Hz}, 1 \mathrm{H}), 7.34(\mathrm{td}, J=7.5,1.2 \mathrm{~Hz}, 1 \mathrm{H}), 7.28-7.24(\mathrm{~m}, 1 \mathrm{H}), 6.58$ (br. s, $1 \mathrm{H})$, $3.82(\mathrm{t}, J=4.8 \mathrm{~Hz}, 2 \mathrm{H}), 3.60(\mathrm{q}, J=5.2 \mathrm{~Hz}, 2 \mathrm{H}), 2.70$ (br. s, $1 \mathrm{H}) ;{ }^{13} \mathrm{C} \mathrm{NMR}\left(101 \mathrm{MHz}, \mathrm{CDCl}_{3}\right) \delta_{\mathrm{C}}$ 168.8, 137.7, 133.5, 131.6, 129.6, 127.8, 119.5, 62.0, 42.9; HRMS (ESI) m/z: $[\mathrm{M}+\mathrm{Na}]^{+}$Calcd for $\mathrm{C}_{9} \mathrm{H}_{10} \mathrm{BrNO}_{2} \mathrm{Na}$ 265.9784, Found 265.9784.

1-Benzyl-N-(2-hydroxyethyl)piperidine-4-carboxamide (12g).Yellow oil (245 mg, 66\%): $\mathrm{v}_{\max }$ (neat) $3437,3233,2922,1651,1599,1537 \mathrm{~cm}^{-1} ;{ }^{1} \mathrm{H}$ NMR (400 MHz, DMSO) $\delta_{\mathrm{H}} 7.71(\mathrm{t}, J=5.5 \mathrm{~Hz}$, 1H), $7.33-7.26(\mathrm{~m}, 4 \mathrm{H}), 7.25-7.21(\mathrm{~m}, 1 \mathrm{H}), 4.62(\mathrm{t}, J=5.5 \mathrm{~Hz}, 1 \mathrm{H}), 3.42(\mathrm{~s}, 2 \mathrm{H}), 3.38-3.33(\mathrm{~m}$, 2H), $3.08(\mathrm{q}, J=6.1 \mathrm{~Hz}, 2 \mathrm{H}), 2.79(\mathrm{~d}, J=11.5 \mathrm{~Hz}, 2 \mathrm{H}), 2.10-2.03(\mathrm{~m}, 1 \mathrm{H}), 1.87(\mathrm{td}, J=11.4,3.0$ $\mathrm{Hz}, 2 \mathrm{H}), 1.63-1.49(\mathrm{~m}, 4 \mathrm{H}) ;{ }^{13} \mathrm{C} \mathrm{NMR}\left(101 \mathrm{MHz}, \mathrm{CDCl}_{3}\right): \delta_{\mathrm{C}} 176.5,138.3,129.3,128.4,127.3$, 
63.4, 62.4, 53.2, 43.5, 42.5, 29.1; HRMS (ESI) $m / z$ : $[\mathrm{M}+\mathrm{H}]^{+}$Calcd for $\mathrm{C}_{15} \mathrm{H}_{23} \mathrm{~N}_{2} \mathrm{O}_{2}$ 263.1754, Found 263.1752.

2-(3-Cyanophenoxy)-N-(2-hydroxyethyl)-2-(naphthalen-1-yl)acetamide (12h). Colourless oil (298 mg, 61\%): $v_{\max }$ (neat) 3350, 3098, 2958, 2232, 1661, 1530, $1248 \mathrm{~cm}^{-1} ;{ }^{1} \mathrm{H}$ NMR (400 MHz, $\left.\mathrm{CDCl}_{3}\right) \delta_{\mathrm{H}} 8.30(\mathrm{~d}, J=8.4 \mathrm{~Hz}, 1 \mathrm{H}), 7.90(\mathrm{dd}, J=12.5,8.1 \mathrm{~Hz}, 2 \mathrm{H}), 7.66-7.56(\mathrm{~m}, 3 \mathrm{H}), 7.52-7.43$ $(\mathrm{m}, 2 \mathrm{H}), 7.34-7.23(\mathrm{~m}, 2 \mathrm{H}), 7.22-7.10(\mathrm{~m}, 1 \mathrm{H}), 7.01-6.91(\mathrm{~m}, 1 \mathrm{H}), 6.28(\mathrm{~s}, 1 \mathrm{H}), 3.70(\mathrm{t}, J=5.1$ $\mathrm{Hz}, 2 \mathrm{H}), 3.58(\mathrm{~s}, 1 \mathrm{H}), 3.50(\mathrm{q}, J=5.2 \mathrm{~Hz}, 2 \mathrm{H}) ;{ }^{13} \mathrm{C} \mathrm{NMR}\left(101 \mathrm{MHz}, \mathrm{CDCl}_{3}\right) \delta_{\mathrm{C}} 157.0,156.9,134.3$, $131.4,131.2,130.9,130.3,129.3,127.4,126.5,126.2,125.5,123.9,123.6,120.9,120.0,118.4,113.7$, 78.7, 66.5, 38.3; HRMS (ESI) $m / z$ : [M+H] $]^{+}$Calcd for $\mathrm{C}_{21} \mathrm{H}_{19} \mathrm{~N}_{2} \mathrm{O}_{3}$ 347.1390, Found 347.1392.

N-(2-Hydroxyethyl)pyrazine-2-carboxamide (12j). White solid (161 $\mathrm{mg}, 68 \%): \mathrm{v}_{\max }$ (neat) 3410, 3261, 2940, 1666, $1564 \mathrm{~cm}^{-1}$; ${ }^{1} \mathrm{H}$ NMR (400 MHz, DMSO) $\delta_{\mathrm{H}} 9.18(\mathrm{~d}, J=1.5 \mathrm{~Hz}, 1 \mathrm{H}), 8.87(\mathrm{~d}$, $J=2.5 \mathrm{~Hz}, 1 \mathrm{H}), 8.78(\mathrm{t}, J=5.2 \mathrm{~Hz}, 1 \mathrm{H}), 8.73-8.72(\mathrm{~m}, 1 \mathrm{H}), 4.81(\mathrm{t}, J=5.6 \mathrm{~Hz}, 1 \mathrm{H}), 3.53(\mathrm{q}, J=6.0$ $\mathrm{Hz}, 2 \mathrm{H}), 3.39$ (q, $J=6.1 \mathrm{~Hz}, 2 \mathrm{H}) ;{ }^{13} \mathrm{C}$ NMR (101 MHz, DMSO) $\delta_{\mathrm{C}} 162.8,147.5,144.7,143.5,143.3$, 59.5, 41.6; HRMS (ESI) $m / z$ : [M+H] $]^{+}$Calcd for $\mathrm{C}_{7} \mathrm{H}_{10} \mathrm{~N}_{3} \mathrm{O}_{2}$ 168.0768, Found 168.0765.

2-Chloro-N-(3-hydroxypropyl)-6-methylpyrimidine-4-carboxamide (12k). Yellow oil (261 mg, 80\%): $v_{\max }$ (neat) $3365,3101,1671, \mathrm{~cm}^{-1} ;{ }^{1} \mathrm{H}$ NMR (500 MHz, $\mathrm{CDCl}_{3}$ ) $\delta_{\mathrm{H}} 8.12$ (br. s, $\left.1 \mathrm{H}\right), 7.91$ (s, 1H), $3.70(\mathrm{t}, J=5.4 \mathrm{~Hz}, 2 \mathrm{H}), 3.64(\mathrm{q}, J=6.4 \mathrm{~Hz}, 2 \mathrm{H}), 2.87$ (br. s, $1 \mathrm{H}), 2.64(\mathrm{~s}, 3 \mathrm{H}), 1.87-1.82$ $(\mathrm{m}, 2 \mathrm{H}) ;{ }^{13} \mathrm{C}$ NMR $\left(126 \mathrm{MHz}, \mathrm{CDCl}_{3}\right) \delta_{\mathrm{C}} 173.7,162.8,160.3,158.8,117.0,59.6,36.7,32.3,24.6$; HRMS (ESI) $m / z$ : [M+H] ${ }^{+}$Calcd for $\mathrm{C}_{9} \mathrm{H}_{13} \mathrm{~N}_{3} \mathrm{O}_{2} \mathrm{Cl} 230.0961$, Found 230.0960.

N-(3-Hydroxypropyl)-6-methylnicotinamide (12l). White solid (207 $\mathrm{mg}, 75 \%): \mathrm{v}_{\max }$ (neat) 3444, 3237, 2926, 2895, 1651, $1539 \mathrm{~cm}^{-1} ;{ }^{1} \mathrm{H}$ NMR $\left(500 \mathrm{MHz}, \mathrm{CDCl}_{3}\right) \delta_{\mathrm{H}} 8.85(\mathrm{~d}, J=2.1 \mathrm{~Hz}, 1 \mathrm{H})$, $8.03(\mathrm{dd}, J=8.1,2.3 \mathrm{~Hz}, 1 \mathrm{H}), 7.44$ (br. s, $1 \mathrm{H}), 7.21(\mathrm{~d}, J=8.1 \mathrm{~Hz}, 1 \mathrm{H}), 3.76(\mathrm{t}, J=5.5 \mathrm{~Hz}, 2 \mathrm{H}), 3.62$ $(\mathrm{q}, J=5.9 \mathrm{~Hz}, 2 \mathrm{H}), 2.58(\mathrm{~s}, 3 \mathrm{H}), 1.85-1.80(\mathrm{~m}, 2 \mathrm{H}), 1 \mathrm{H}$ missing (exchangeable); ${ }^{13} \mathrm{C}$ NMR $(126$ $\left.\mathrm{MHz}, \mathrm{CDCl}_{3}\right) \delta_{\mathrm{C}} 166.5,161.7,147.4,135.9,127.6,123.4,60.6,38.2,31.8,24.6$; HRMS (ESI) $m / z$ : $[\mathrm{M}+\mathrm{Na}]^{+}$Calcd for $\mathrm{C}_{10} \mathrm{H}_{14} \mathrm{~N}_{2} \mathrm{O}_{2} \mathrm{Na} 217.0941$, Found 217.0945.

$\mathrm{N}$-(2-Hydroxyethyl)-4H-1,2,4-triazole-3-carboxamide (12m). White solid (62 mg, 28\%): $\mathrm{v}_{\max }$ (neat) $3406,3273,3102,2982,1644,1563 \mathrm{~cm}^{-1} ;{ }^{1} \mathrm{H}$ NMR (400 MHz, DMSO) $\delta_{\mathrm{H}} 8.43(\mathrm{~s}, 1 \mathrm{H}), 4.78$ 
(br. s, 1H), 3.49 (t, $J=6.2 \mathrm{~Hz}, 2 \mathrm{H}), 3.34-3.30(\mathrm{~m}, 3 \mathrm{H}), 1 \mathrm{H}$ missing (exchangeable); ${ }^{13} \mathrm{C}$ NMR $(101$ MHz, DMSO) $\delta_{\mathrm{C}} 158.2,147.0,59.5,41.4,1 \mathrm{C}$ missing (coincident); HRMS (ESI) $m / z:[\mathrm{M}+\mathrm{H}]^{+} \mathrm{Calcd}$ for $\mathrm{C}_{5} \mathrm{H}_{9} \mathrm{~N}_{4} \mathrm{O}_{2}$ 157.0720, Found 157.0718.

N-(2-Hydroxyethyl)-1-methyl-1H-1,2,4-triazole-5-carboxamide (12n). White solid (227 mg, 94\%): $v_{\max }$ (neat) 3237, 3101, 1671, $1580 \mathrm{~cm}^{-1} ;{ }^{1} \mathrm{H}$ NMR (400 MHz, $\left.\mathrm{CDCl}_{3}\right) \delta_{\mathrm{H}} 7.87$ (br. s, $\left.1 \mathrm{H}\right), 7.82$ (s, 1H), $4.25(\mathrm{~s}, 3 \mathrm{H}), 3.83(\mathrm{t}, J=5.2 \mathrm{~Hz}, 2 \mathrm{H}), 3.60(\mathrm{q}, J=5.5 \mathrm{~Hz}, 2 \mathrm{H}), 3.01$ (br. s, $1 \mathrm{H}) ;{ }^{13} \mathrm{C}$ NMR $(101$ $\left.\mathrm{MHz}, \mathrm{CDCl}_{3}\right) \delta_{\mathrm{C}} 157.9,149.5,146.3,61.6,42.2,38.5$; HRMS (ESI) $m / z:[\mathrm{M}+\mathrm{Na}]^{+} \mathrm{Calcd}$ for $\mathrm{C}_{6} \mathrm{H}_{10} \mathrm{~N}_{4} \mathrm{O}_{2} \mathrm{Na}$ 193.0691, Found 193.0693.

N-(2-Hydroxyethyl)-1H-pyrrole-2-carboxamide (12o). Yellow oil (201 mg, 92\%): $\mathrm{v}_{\max }$ (neat) $3277,2940,2878,1607,1560 \mathrm{~cm}^{-1} ;{ }^{1} \mathrm{H}$ NMR (400 MHz, DMSO) $\delta_{\mathrm{H}} 11.41$ (br. s, $\left.1 \mathrm{H}\right), 7.96$ (t, $J=5.6$ $\mathrm{Hz}, 1 \mathrm{H}), 6.83(\mathrm{td}, J=2.7,1.5 \mathrm{~Hz}, 1 \mathrm{H}), 6.76-6.74(\mathrm{~m}, 1 \mathrm{H}), 6.06(\mathrm{dt}, J=3.6,2.4 \mathrm{~Hz}, 1 \mathrm{H}), 4.72($ br. s, $1 \mathrm{H}), 3.47(\mathrm{t}, J=6.3 \mathrm{~Hz}, 2 \mathrm{H}), 3.27(\mathrm{q}, J=6.1 \mathrm{~Hz}, 2 \mathrm{H}) ;{ }^{13} \mathrm{C}$ NMR $(101 \mathrm{MHz}, \mathrm{DMSO}) \delta_{\mathrm{C}} 160.9,126.4$, 121.2, 109.9, 108.5, 60.1, 41.4; HRMS (ESI) $m / z$ : $[\mathrm{M}+\mathrm{Na}]^{+}$Calcd for $\mathrm{C}_{7} \mathrm{H}_{10} \mathrm{~N}_{2} \mathrm{O}_{2} \mathrm{Na}$ 177.0632, Found 177.0631.

N-(2-Hydroxyethyl)pyrimidine-2-carboxamide (12p). White solid (195 mg, 82\%); Also prepared as follows: To a solution of pyrimidine-2-carboxylic acid (176 mg, $1.42 \mathrm{mmol})$ and $\mathrm{Et}_{3} \mathrm{~N}$ (395 $\mu \mathrm{L}, 2.84 \mathrm{mmol})$ in $\mathrm{CH}_{2} \mathrm{Cl}_{2}(1 \mathrm{~mL})$ was added HATU (648 $\left.\mathrm{mg}, 1.7 \mathrm{mmol}\right)$ and ethanolamine (86 $\mu \mathrm{L}, 1.42 \mathrm{mmol}$ ). The reaction mixture was stirred at room temperature for $16 \mathrm{~h}$, then washed with water and $2 \mathrm{M} \mathrm{HCl}$, dried $\left(\mathrm{MgSO}_{4}\right)$, filtered, and concentrated to a residue that was purified by flash column chromatography ( $4 \%$ methanol/ $\mathrm{CH}_{2} \mathrm{Cl}_{2}$ ) to afford the title compound as a white solid (180 mg, 76\%). $v_{\max }$ (neat) $3403,3310,2919,1651,1538 \mathrm{~cm}^{-1} ;{ }^{1} \mathrm{H} \mathrm{NMR}\left(400 \mathrm{MHz}, \mathrm{CDCl}_{3}\right) \delta_{\mathrm{H}} 8.85(\mathrm{~d}, J=$ $4.8 \mathrm{~Hz}, 2 \mathrm{H}), 8.48$ (br. s, $1 \mathrm{H}), 7.42(\mathrm{t}, J=4.9 \mathrm{~Hz}, 1 \mathrm{H}), 3.87-3.85(\mathrm{~m}, 2 \mathrm{H}), 3.68(\mathrm{q}, J=5.8 \mathrm{~Hz}, 2 \mathrm{H})$, 3.36 (br. s, $1 \mathrm{H}) ;{ }^{13} \mathrm{C}$ NMR $\left(101 \mathrm{MHz}, \mathrm{CDCl}_{3}\right) \delta_{\mathrm{C}} 163.3,157.7,157.6,122.8,62.0,42.8,1 \mathrm{C}$ missing (coincident); HRMS (ESI) $m / z$ : $[\mathrm{M}+\mathrm{H}]^{+}$Calcd for $\mathrm{C}_{7} \mathrm{H}_{10} \mathrm{~N}_{3} \mathrm{O}_{2}$ 168.0768, Found 168.0765.

N-(2-Hydroxyethyl)-5-methoxy-3,4-dihydro-2H-pyrrole-2-carboxamide (12s). White solid (136 mg, 61\%): $\cup_{\max }$ (neat) 3410, 3277, 3090, 2931, 1663, 1647, $1559 \mathrm{~cm}^{-1} ;{ }^{1} \mathrm{H}$ NMR (500 MHz, DMSO) $\delta_{\mathrm{H}} 8.20(\mathrm{t}, J=4.8 \mathrm{~Hz}, 1 \mathrm{H}), 4.73$ (br. s, $\left.1 \mathrm{H}\right), 4.02-4.00(\mathrm{~m}, 1 \mathrm{H}), 3.42(\mathrm{t}, J=6.0 \mathrm{~Hz}, 2 \mathrm{H})$, 
$3.15(\mathrm{q}, J=5.8 \mathrm{~Hz}, 2 \mathrm{H}), 2.60(\mathrm{~s}, 3 \mathrm{H}), 2.26-2.15(\mathrm{~m}, 3 \mathrm{H}), 1.81-1.76(\mathrm{~m}, 1 \mathrm{H}) ;{ }^{13} \mathrm{C} \mathrm{NMR}(126 \mathrm{MHz}$, DMSO): $\delta_{\mathrm{C}} 174.5,171.1,61.8,59.7,41.5,29.3,27.9,22.5$; HRMS (ESI) $\mathrm{m} / z$ : $[\mathrm{M}+\mathrm{H}]^{+}$Calcd for $\mathrm{C}_{8} \mathrm{H}_{15} \mathrm{~N}_{2} \mathrm{O}_{3}$ 187.1077, Found 187.1075.

5-(4-Bromophenyl)-N-(2-hydroxyethyl)-3-methylisoxazole-4-carboxamide (12t). White solid (305 mg, 66\%): $v_{\max }$ (neat) $3271,3112,2955,1643,1545 \mathrm{~cm}^{-1} ;{ }^{1} \mathrm{H}$ NMR $\left(400 \mathrm{MHz}, \mathrm{CDCl}_{3}\right) \delta_{\mathrm{H}} 7.70-$ 7.67 (m, 2H), $7.65-7.63(\mathrm{~m}, 2 \mathrm{H}), 6.13$ (br. s, 1H), $3.78(\mathrm{t}, J=5.0 \mathrm{~Hz}, 2 \mathrm{H}), 3.56$ (q, $J=5.2 \mathrm{~Hz}, 2 \mathrm{H})$, 2.46 (s, 3H), 1.96 (br. s, $1 \mathrm{H}) ;{ }^{13} \mathrm{C}$ NMR (101 MHz, $\left.\mathrm{CDCl}_{3}\right) \delta_{\mathrm{C}} 167.1,162.9,160.0,132.6,129.6$, 126.0, 125.7, 112.3, 61.9, 42.4, 11.2; HRMS (ESI) $m / z$ : $[\mathrm{M}+\mathrm{H}]^{+}$Calcd for $\mathrm{C}_{13} \mathrm{H}_{14} \mathrm{BrN}_{2} \mathrm{O}_{3}$ 325.0182, Found 325.0184 .

(S)-(4-bromo-2-chlorophenyl)(2-(hydroxymethyl)pyrrolidin-1-yl)methanone $\quad(\mathbf{1 3 a}){ }^{15} \quad 2.5 \quad \mathrm{~g}$ scale. To an oven-dried Schlenk tube containing BEMP $(290 \mu \mathrm{L}, 1 \mathrm{mmol})$ and acetonitrile $(5 \mathrm{~mL})$ was added methyl 4-bromo-2-chlorobenzoate (12.5 g, $10 \mathrm{mmol})$ and $(S)-(+)-2-($ hydroxymethyl)pyrrolidine $(987 \mu \mathrm{L}, 10 \mathrm{mmol})$. The reaction mixture was stirred at room temperature for $15 \mathrm{~h}$ then concentrated to a residue that was purified by flash column chromatography ( $4 \%$ methanol/ $\mathrm{CH}_{2} \mathrm{Cl}_{2}$ ) to afford the title compound as a colourless oil (2.92 g, 92\%): $v_{\max }$ (neat) 3389, 2949, 2876, 1612, 1581, $1425 \mathrm{~cm}^{-1}$; ${ }^{1} \mathrm{H}$ NMR $\left(500 \mathrm{MHz}, \mathrm{CDCl}_{3}\right) \delta_{\mathrm{H}} 7.60(\mathrm{~d}, J=1.5 \mathrm{~Hz}, 1 \mathrm{H}), 7.48(\mathrm{dd}, J=8.3,1.8 \mathrm{~Hz}, 1 \mathrm{H}), 7.21(\mathrm{~d}, J=$ $8.0 \mathrm{~Hz}, 1 \mathrm{H}), 4.36(\mathrm{qd}, J=7.3,3.6 \mathrm{~Hz}, 1 \mathrm{H}), 3.82(\mathrm{dd}, J=11.5,3.0 \mathrm{~Hz}, 1 \mathrm{H}), 3.76(\mathrm{dd}, J=11.8,7.3 \mathrm{~Hz}$, 1H), $3.27-3.26(\mathrm{~m}, 2 \mathrm{H}), 2.20-2.15(\mathrm{~m}, 1 \mathrm{H}), 1.92-1.87(\mathrm{~m}, 1 \mathrm{H}), 1.86-1.77(\mathrm{~m}, 1 \mathrm{H}), 1.74-1.67$ (m, 1H), 1H missing (exchangeable); ${ }^{13} \mathrm{C}$ NMR $\left(126 \mathrm{MHz}, \mathrm{CDCl}_{3}\right) \delta_{\mathrm{C}} 168.3,136.0,132.7,130.9$, 128.8, 123.7, 66.8, 61.8, 49.6, 28.8, 24.7, 1C missing (coincident); HRMS (ESI) $m / z:[\mathrm{M}+\mathrm{H}]^{+} \mathrm{Calcd}$ for $\mathrm{C}_{12} \mathrm{H}_{14} \mathrm{BrClNO}_{2}$ 317.9891, Found 317.9896; $[\alpha]_{\mathrm{D}}^{20}-50\left(c 2.0, \mathrm{CHCl}_{3}\right)$.

(S,E)-1-(2-(Hydroxymethyl)pyrrolidin-1-yl)-3-phenylprop-2-en-1-one (13b). ${ }^{32}$ Yellow oil (302 mg, 92\%): $v_{\max }$ (neat) $3350,2949,2876,1645,1582,1422 \mathrm{~cm}^{-1} ;{ }^{1} \mathrm{H}$ NMR $\left(400 \mathrm{MHz}, \mathrm{CDCl}_{3}\right) \delta_{\mathrm{H}} 7.63$ - $7.56(\mathrm{~m}, 1 \mathrm{H}), 7.45-7.42(\mathrm{~m}, 2 \mathrm{H}), 7.31-7.20(\mathrm{~m}, 3 \mathrm{H}), 6.90(\mathrm{~d}, J=15.2 \mathrm{~Hz}, 0.23 \mathrm{H}$, minor rotamer), 6.66 (d, $J=15.2 \mathrm{~Hz}, 0.73 \mathrm{H}$, major rotamer), 5.30 (br. s, $1 \mathrm{H}$ ), 4.23 (app. quin, $J=5.7 \mathrm{~Hz}$, $0.75 \mathrm{H}$ major rotamer), $4.15-4.10(\mathrm{~m}, 0.27 \mathrm{H}$, minor rotamer), $3.61-3.47(\mathrm{~m}, 4 \mathrm{H}$, major + minor rotamers), $1.98-1.86(\mathrm{~m}, 2 \mathrm{H}$, major + minor rotamers), $1.84-1.76(\mathrm{~m}, 1.2 \mathrm{H}$, major rotamer), $1.69-$ 
$1.62\left(\mathrm{~m}, 0.78 \mathrm{H}\right.$, minor rotamer); ${ }^{13} \mathrm{C} \mathrm{NMR}\left(101 \mathrm{MHz}, \mathrm{CDCl}_{3}\right.$, major rotamer) $\delta_{\mathrm{C}} 166.6,142.6,134.8$, $129.7,128.7,127.8,118.3,65.9,60.8,47.8,27.8,24.1 ;{ }^{13} \mathrm{C} \mathrm{NMR}\left(101 \mathrm{MHz}, \mathrm{CDCl}_{3}\right.$, minor rotamer) $\delta_{\mathrm{C}} 165.3,141.4,135.1,129.2,128.5,127.7,119.1,64.1,58.9,46.1,28.2,21.7$; HRMS (ESI) $m / z$ : $[\mathrm{M}+\mathrm{H}]^{+}$Calcd for $\mathrm{C}_{14} \mathrm{H}_{18} \mathrm{NO}_{2}$ 232.1332, Found 232.1331; $[\alpha]_{\mathrm{D}}{ }^{20}-39$ (c 2.1, MeOH).

(S)-(2-(Hydroxymethyl)pyrrolidin-1-yl)(1H-indol-5-yl)methanone (13d). Colourless oil (197 mg, 57\%): $v_{\max }$ (neat) 3318, 3211, 2963, 2891, 2846, 1629, $1554 \mathrm{~cm}^{-1} ;{ }^{1} \mathrm{H}$ NMR (400 MHz, DMSO) $\delta_{\mathrm{H}} 11.25(\mathrm{~s}, 1 \mathrm{H}), 7.72($ br. s, $1 \mathrm{H}), 7.41-7.40(\mathrm{~m}, 2 \mathrm{H}), 7.25-7.24(\mathrm{~m}, 1 \mathrm{H}), 6.49(\mathrm{t}, J=2.0 \mathrm{~Hz}, 1 \mathrm{H})$, $4.81(\mathrm{~s}, 1 \mathrm{H}), 4.18-4.08(\mathrm{~m}, 1 \mathrm{H}), 3.68-3.59(\mathrm{~m}, 1 \mathrm{H}), 3.52-3.49(\mathrm{~m}, 2 \mathrm{H}), 3.42-3.38(\mathrm{~m}, 1 \mathrm{H}), 1.98$ - 1.87 (m, 3H), 1.66 (br. s, $1 \mathrm{H}) ;{ }^{13} \mathrm{C}$ NMR (126 MHz, DMSO) $\delta_{\mathrm{C}} 170.3,136.3,128.1,126.7,126.4$, $120.7,119.8,110.8,101.8,61.8,58.7,50.5,27.2,24.7$; HRMS (ESI) $m / z:[\mathrm{M}+\mathrm{H}]^{+}$Calcd for $\mathrm{C}_{14} \mathrm{H}_{17} \mathrm{~N}_{2} \mathrm{O}_{2} 245.1285$, Found 245.1284; $[\alpha]_{\mathrm{D}}^{20}-139(c 1.0, \mathrm{MeOH})$.

N-Benzyl-N-(2-hydroxyethyl)-2-phenylacetamide (13g). White solid (371 $\mathrm{mg}, 97 \%): \mathrm{v}_{\max }$ (neat) 3399, 3333, 3063, 2934, 1624, $1489 \mathrm{~cm}^{-1} ;{ }^{1} \mathrm{H}$ NMR (400 MHz, $\left.\mathrm{CDCl}_{3}\right) \delta_{\mathrm{H}} 7.35-7.19(\mathrm{~m}, 8 \mathrm{H})$, $7.17-7.15(\mathrm{~m}, 1 \mathrm{H}), 7.09(\mathrm{~d}, J=6.8 \mathrm{~Hz}, 1 \mathrm{H}), 4.62(\mathrm{~s}, 0.73 \mathrm{H}$, minor rotamer), 4.58 (s, 1.27H, major rotamer), $3.86(\mathrm{~s}, 0.77 \mathrm{H}$, minor rotamer), $3.72-3.67(\mathrm{~m}, 2.41 \mathrm{H}$, major rotamer), 3.59 (t, $J=5.4 \mathrm{~Hz}$, $0.76 \mathrm{H}$, minor rotamer), $3.53(\mathrm{t}, J=5.0 \mathrm{~Hz}, 1.30 \mathrm{H}$, major rotamer), $3.34(\mathrm{t}, J=5.6 \mathrm{~Hz}, 0.71 \mathrm{H}$, minor rotamer), 2.43 (br. s, $1 \mathrm{H}) ;{ }^{13} \mathrm{C} \mathrm{NMR}\left(101 \mathrm{MHz}, \mathrm{CDCl}_{3}\right.$, major rotamer) $\delta_{\mathrm{C}} 174.0,136.4,134.8,129.2$, 129.0, 128.8, 128.1, 127.2, 126.6, 62.3, 53.1, 49.4, 41.4; ${ }^{13} \mathrm{C} \mathrm{NMR}\left(101 \mathrm{MHz}, \mathrm{CDCl}_{3}\right.$, minor rotamer) $\delta_{\mathrm{C}} 174.0,137.9,135.5,129.1,128.9,128.7,128.2,127.6,127.0,60.3,50.3,48.8,41.0$; HRMS (ESI) $m / z:[\mathrm{M}+\mathrm{H}]^{+}$Calcd for $\mathrm{C}_{17} \mathrm{H}_{20} \mathrm{NO}_{2} 270.1489$, Found 270.1489 .

5-(4-Bromophenyl)-N-(2-hydroxyethyl)-N,3-dimethylisoxazole-4-carboxamide

(13h).

Colourless oil (433 mg, 90\%): $\mathrm{v}_{\max }$ (neat) 3399, 2934, 1612, $1398 \mathrm{~cm}^{-1} ;{ }^{1} \mathrm{H}$ NMR (400 MHz, $\mathrm{CDCl}_{3}$, major rotamer): $\delta_{\mathrm{H}} 7.64-7.55(\mathrm{~m}, 4 \mathrm{H}), 3.85(\mathrm{t}, J=5.4 \mathrm{~Hz}, 1.30 \mathrm{H}$, major rotamer), $3.70(\mathrm{~s}, 1.13 \mathrm{H}$, major rotamer), 3.49 (t, $J=4.8 \mathrm{~Hz}, 0.64 \mathrm{H}$ minor rotamer), 3.10 (s, 1.03H, minor rotamer), 2.85 (s, $3 \mathrm{H}), 2.30\left(\mathrm{~s}, 2 \mathrm{H}\right.$, major rotamer), 2.27 (s, 0.98H, minor rotamer), $1 \mathrm{H}$ missing (exchangeable); ${ }^{13} \mathrm{C}$ NMR $\left(101 \mathrm{MHz}, \mathrm{CDCl}_{3}\right.$, major rotamer) $\delta_{\mathrm{C}} 164.9,164.5,159.1,132.6,128.0,125.7,125.5,111.4$, 60.2, 50.1, 37.2, 10.4; ${ }^{13} \mathrm{C} \mathrm{NMR}\left(101 \mathrm{MHz}, \mathrm{CDCl}_{3}\right.$, minor rotamer) $\delta_{\mathrm{C}} 164.4,164.1,159.5,132.5$, 
127.9, 125.8, 125.3, 111.8, 58.8, 52.8, 33.0, 10.3, 1C missing (overlapping peaks); HRMS (ESI) $m / z$ : $[\mathrm{M}+\mathrm{H}]^{+}$Calcd for $\mathrm{C}_{14} \mathrm{H}_{16} \mathrm{BrN}_{2} \mathrm{O}_{3} 339.0339$, Found 339.0336.

N,N-Bis(2-hydroxyethyl)-2-phenylacetamide (13i). ${ }^{33}$ White solid (279 mg, 81\%): $\mathrm{v}_{\max }$ (neat) $3329,3204,2903,1601,1479 \mathrm{~cm}^{-1} ;{ }^{1} \mathrm{H}$ NMR $(500 \mathrm{MHz}, \mathrm{DMSO}) \delta_{\mathrm{H}} 7.74(\mathrm{~d}, J=8.0 \mathrm{~Hz}, 1 \mathrm{H}), 7.30-$ $7.24(\mathrm{~m}, 4 \mathrm{H}), 7.22-7.19(\mathrm{~m}, 1 \mathrm{H}), 4.60(\mathrm{t}, J=5.3 \mathrm{~Hz}, 2 \mathrm{H}), 3.72-3.66(\mathrm{~m}, 1 \mathrm{H}), 3.43(\mathrm{~s}, 2 \mathrm{H}), 3.40(\mathrm{t}$, $J=5.3 \mathrm{~Hz}, 4 \mathrm{H}) ;{ }^{13} \mathrm{C} \mathrm{NMR}(126 \mathrm{MHz}, \mathrm{DMSO}) \delta_{\mathrm{C}} 170.0,136.6,129.0,128.1,126.2,60.152 .9,42.3$; HRMS (ESI) $m / z$ : [M+Na] $]^{+}$Calcd for $\mathrm{C}_{11} \mathrm{H}_{15} \mathrm{NO}_{3} \mathrm{Na} 232.0944$, Found 232.0941.

N-(2-Hydroxy-2-methylpropyl)-4-(trifluoromethyl)benzamide (13l). White solid (189 mg, 51\%): $v_{\max }$ (neat) $3447,3312,2980,1639,1547 \mathrm{~cm}^{-1} ;{ }^{1} \mathrm{H}$ NMR (500 MHz, DMSO) $\delta_{\mathrm{H}} 8.47$ (t, $J=6.0$ $\mathrm{Hz}, 1 \mathrm{H}), 8.05(\mathrm{~d}, J=8.1 \mathrm{~Hz}, 2 \mathrm{H}), 7.84(\mathrm{~d}, J=8.3 \mathrm{~Hz}, 2 \mathrm{H}), 4.54(\mathrm{~s}, 1 \mathrm{H}), 3.27(\mathrm{~d}, J=6.2 \mathrm{~Hz}, 2 \mathrm{H}), 1.11$ $(\mathrm{s}, 6 \mathrm{H}) ;{ }^{13} \mathrm{C}$ NMR $(126 \mathrm{MHz}, \mathrm{DMSO}) \delta_{\mathrm{C}} 165.6,138.6,131.0\left(\mathrm{q},{ }^{2} J_{C F}=32.2 \mathrm{~Hz}\right), 128.2,125.2\left(\mathrm{q},{ }^{3} J_{C F}\right.$ $=3.2 \mathrm{~Hz}), 124.0\left(\mathrm{q},{ }^{1} J_{C F}=272.2 \mathrm{~Hz}\right), 69.8,50.3,27.4$; HRMS (ESI) $m / z:[\mathrm{M}+\mathrm{Na}]^{+}$Calcd for $\mathrm{C}_{12} \mathrm{H}_{14} \mathrm{NO}_{2} \mathrm{~F}_{3} \mathrm{Na} 284.0869$, Found 284.0867.

(S)-4-Benzyloxazolidin-2-one $(\mathbf{1 4 a}) .{ }^{25}$ White solid (171 mg, 68\%): $v_{\max }$ (neat) 3263, 2921, $1707 \mathrm{~cm}^{-1} ;{ }^{1} \mathrm{H}$ NMR $\left(400 \mathrm{MHz}, \mathrm{CDCl}_{3}\right) \delta_{\mathrm{H}} 7.35(\mathrm{tt}, J=8.1,1.8 \mathrm{~Hz}, 2 \mathrm{H}), 7.30(\mathrm{dt}, J=5.1,2.1 \mathrm{~Hz}$, 1H), $7.20-7.17$ (m, 2H), 5.19 (br. s, $1 \mathrm{H}), 4.50-4.46(\mathrm{~m}, 1 \mathrm{H}), 4.17$ (dd, $J=8.5,5.6 \mathrm{~Hz}, 1 \mathrm{H}), 4.13-$ $4.06(\mathrm{~m}, 1 \mathrm{H}), 2.93-2.84(\mathrm{~m}, 2 \mathrm{H}) ;{ }^{13} \mathrm{C} \mathrm{NMR}\left(126 \mathrm{MHz}, \mathrm{CDCl}_{3}\right) \delta_{\mathrm{C}} 159.4,136.2,129.2,129.1,127.5$, 69.9, 54.0, 41.7; HRMS (ESI) $m / z$ : $[\mathrm{M}+\mathrm{H}]^{+}$Calcd for $\mathrm{C}_{10} \mathrm{H}_{12} \mathrm{NO}_{2}$ 178.0863, Found 178.0858; $[\alpha]_{\mathrm{D}}{ }^{20}-$ $60\left(c 1.0, \mathrm{CHCl}_{3}\right), \mathrm{lit}^{34}[\alpha]_{\mathrm{D}}{ }^{20}-62\left(c 1.0, \mathrm{CHCl}_{3}\right)$.

(S)-4-Phenyloxazolidin-2-one (14b). ${ }^{35}$ White solid (153 mg, 66\%): $v_{\max }$ (neat) 3237, 3142, $1705 \mathrm{~cm}^{-1} ;{ }^{1} \mathrm{H}$ NMR $\left(400 \mathrm{MHz}, \mathrm{CDCl}_{3} \delta_{\mathrm{H}} 7.44-7.33\right.$ (m, 5H), 6.12 (br. s, $\left.1 \mathrm{H}\right), 4.97$ (t, $J=7.8 \mathrm{~Hz}$, $1 \mathrm{H}), 4.74(\mathrm{t}, J=8.7 \mathrm{~Hz}, 1 \mathrm{H}), 4.19(\mathrm{dd}, J=8.6,6.9 \mathrm{~Hz}, 1 \mathrm{H}) ;{ }^{13} \mathrm{C}$ NMR $\left(101 \mathrm{MHz}, \mathrm{CDCl}_{3}\right) \delta_{\mathrm{C}} 160.0$, 139.7, 129.4, 129.0, 126.2, 72.7, 56.6; HRMS (ESI) $m / z$ : $[\mathrm{M}+\mathrm{Na}]^{+}$Calcd for $\mathrm{C}_{9} \mathrm{H}_{9} \mathrm{NO}_{2} \mathrm{Na}_{186.0521}$, Found 186.0523; $[\alpha]_{\mathrm{D}}^{20}+53\left(c 2.0, \mathrm{CHCl}_{3}\right), \mathrm{lit}^{36}[\alpha]_{\mathrm{D}}^{20}+48\left(c\right.$ 2.0, $\left.\mathrm{CHCl}_{3}\right)$.

(S)-4-Isopropyloxazolidin-2-one (14c). ${ }^{34}$ White solid (154 mg, 84\%): $\mathrm{v}_{\max }$ (neat) 3253, 3153, 2958, 1721, $1472 \mathrm{~cm}^{-1} ;{ }^{1} \mathrm{H}$ NMR $\left(500 \mathrm{MHz}, \mathrm{CDCl}_{3}\right): \delta_{\mathrm{H}} 6.23$ (br. s, $\left.1 \mathrm{H}\right), 4.45$ (t, $\left.J=8.6 \mathrm{~Hz}, 1 \mathrm{H}\right), 4.11$ $(\mathrm{dd}, J=8.7,6.3 \mathrm{~Hz}, 1 \mathrm{H}), 3.64-3.59(\mathrm{~m}, 1 \mathrm{H}), 1.74(\mathrm{dq}, J=13.5,6.8 \mathrm{~Hz}, 1 \mathrm{H}), 0.97(\mathrm{~d}, J=6.7 \mathrm{~Hz}$, 
3H), $0.91(\mathrm{~d}, J=6.8 \mathrm{~Hz}, 3 \mathrm{H}) ;{ }^{13} \mathrm{C} \mathrm{NMR}\left(126 \mathrm{MHz}, \mathrm{CDCl}_{3}\right) \delta_{\mathrm{C}} 160.7,68.8,58.6,32.9,18.2,17.8$; HRMS (ESI) $m / z:[\mathrm{M}+\mathrm{H}]^{+}$Calcd for $\mathrm{C}_{6} \mathrm{H}_{12} \mathrm{NO}_{2}$ 130.0863, Found 130.0862; $[\alpha]_{\mathrm{D}}{ }^{20}+6\left(c 1.0, \mathrm{CHCl}_{3}\right)$, $\operatorname{lit}^{37}[\alpha]_{\mathrm{D}}^{20}+8\left(c 1.0, \mathrm{CHCl}_{3}\right)$.

Oxazolidin-2-one $(\mathbf{1 4 d}) .{ }^{33}$ White solid (73 mg, 51\%): $v_{\max }$ (neat) 3248, 2989, 2919, 1712, $1485 \mathrm{~cm}^{-1} ;{ }^{1} \mathrm{H}$ NMR (500 MHz, DMSO) $\delta_{\mathrm{H}} 7.45$ (br. s, $\left.1 \mathrm{H}\right), 4.30-4.27(\mathrm{~m}, 2 \mathrm{H}), 3.46-3.42(\mathrm{~m}, 2 \mathrm{H})$;

${ }^{13} \mathrm{C}$ NMR $\left(126 \mathrm{MHz}, \mathrm{CDCl}_{3}\right.$ ) $\delta_{\mathrm{C}} 161.2,65.2,40.8$; HRMS (EI) $\mathrm{m} / \mathrm{z}$ : [M] ${ }^{+}$Calcd for $\mathrm{C}_{3} \mathrm{H}_{5} \mathrm{NO}_{2}$ 87.0315, Found 87.0316.

(S)-Tetrahydropyrrolo[1,2-c]oxazol-3(1H)-one $(14 e) .{ }^{38}$ Yellow oil (125 mg, 69\%): $\mathrm{U}_{\max }$ (neat): 2974, 2911, 1738, $1481 \mathrm{~cm}^{-1} ;{ }^{1} \mathrm{H}$ NMR $\left(400 \mathrm{MHz}, \mathrm{CDCl}_{3}\right) \delta 4.45$ (dd, $J=8.9,7.9 \mathrm{~Hz}$, $1 \mathrm{H}), 4.10(\mathrm{dd}, J=8.9,3.6 \mathrm{~Hz}, 1 \mathrm{H}), 3.88-3.81(\mathrm{~m}, 1 \mathrm{H}), 3.60-3.53(\mathrm{~m}, 1 \mathrm{H}), 3.13-3.08(\mathrm{~m}, 1 \mathrm{H})$, $2.07-1.97(\mathrm{~m}, 2 \mathrm{H}), 1.93-1.83(\mathrm{~m}, 1 \mathrm{H}), 1.46-1.36(\mathrm{~m}, 1 \mathrm{H}) ;{ }^{13} \mathrm{C} \mathrm{NMR}\left(101 \mathrm{MHz}, \mathrm{CDCl}_{3}\right) \delta 161.8$, 67.8, 59.5, 45.8, 30.7, 25.7; HRMS (ESI) $m / z$ : $[\mathrm{M}+\mathrm{H}]^{+}$Calcd for $\mathrm{C}_{6} \mathrm{H}_{10} \mathrm{NO}_{2}$ 128.0706, Found $128.0704 ;[\alpha]_{\mathrm{D}}^{20}-68(c 2.3, \mathrm{MeOH})$.

4-(Hydroxymethyl)oxazolidin-2-one (14f). ${ }^{39}$ Yellow oil (144 mg, 87\%):

$\mathrm{U}_{\max }$ (neat): 3331, 3242, 2933, 2878, 1722, $1418 \mathrm{~cm}^{-1} ;{ }^{1} \mathrm{H}$ NMR (500 MHz, DMSO) $\delta 7.57$ (s, 1H), $4.94(\mathrm{t}, J=5.4 \mathrm{~Hz}, 1 \mathrm{H}), 4.30(\mathrm{t}, J=8.6 \mathrm{~Hz}, 1 \mathrm{H}), 4.05(\mathrm{dd}, J=8.5,5.0 \mathrm{~Hz}, 1 \mathrm{H}), 3.78-3.71(\mathrm{~m}, 1 \mathrm{H})$, 3.37 - $3.35(\mathrm{~m}, 2 \mathrm{H}) ;{ }^{13} \mathrm{C}$ NMR (126 MHz, DMSO) $\delta 159.1,64.4,62.7,53.2$; HRMS (ESI) $m / z$ : $[\mathrm{M}+\mathrm{H}]^{+}$Calcd for $\mathrm{C}_{4} \mathrm{H}_{8} \mathrm{NO}_{3}$ 118.0499, Found 118.0496.

\section{Acknowledgements}

We thank AstraZeneca and the EPSRC for financial support of this work. HRMS data was generated by the EPSRC National Mass Spectrometry Service at the University of Swansea, UK.

\section{Supporting Information}

Copies of spectroscopic data $\left({ }^{1} \mathrm{H}\right.$ and ${ }^{13} \mathrm{C}$ NMR $)$ for all products. This material is available free of charge via the Internet at http://pubs.acs.org. 


\section{References}

1 Pattabiraman, V. R.; Bode, J. W. Nature, 2011, 480, 471-479.

2 Peptides, Synthesis, Structures and Applications; Gutte, B., Ed.; Academic Press: San Diego, 1995.

3 Roughley, S. D.; Jordan, A. M. J. Med. Chem. 2011, 54, 3451-3479.

4 Cooper, T. W. J.; Campbell, I. B.; Macdonald, S. J. F. Angew. Chem. Int. Ed. 2010, 49, 8082-8091.

5 For a review see: El-Faham, A.; Albericio, F. Chem. Rev. 2011, 111, 6557-6602.

6 Constable, D. J. C.; Dunn, P. J.; Hayler, J. D.; Humphrey, G. R.; Leazer, Jr., J. L.; Linderman, R. J.; Lorenz, K.; Manley, J.; Pearlman, B. A.; Wells, A.; Zaks, A.; Zhang, T. Y. Green Chem. 2007, 9, 411-420.

7 For a recent review see: Lundberg, H.; Tinnis, F.; Selander, N.; Adolfsson, H. Chem. Soc. Rev. 2014, 42, 2714-2742.

8 Allen, C. L.; Chhatwal, A. R.; Williams, J. M. J. Chem. Commun. 2012, 48, 666-668.

9 Lundberg, H.; Tinnis, F.; Adolfsson, H. Synlett 2012, 23, 2201-2204.

10 Morimoto, H.; Fujiwara, R.; Shimizu, Y.; Morisaki, K.; Ohshima, T.; Org. Lett. 2014, 16, 20182021.

11 Al-Zoubi, R. M.; Marion, O.; Hall, D. G. Angew. Chem., Int. Ed. 2008, 47, 2876-2879.

12 Ishihara, K.; Ohara, S.; Yamamoto, H. J. Org. Chem. 1996, 61, 4196-4197.

13 Arnold, K.; Batsanov, A. S.; Davies, B.; Whiting, A. Green Chem. 2008, 10, 124-134.

14 Tuccio, B.; Ferre, E.; Comeau, L.; Tetrahedron Lett. 1991, 32, 2763-2764.

15 Caldwell, N.; Jamieson, C.; Simpson, I.; Tuttle, T.; Org. Lett. 2013, 15, 2506-2509.

16 Carlson, R. Design and Optimization in Organic Synthesis; Elsevier: Amsterdam, 1992; Chapter 2. 17 Schwesinger, R. Chimia 1985, 39, 269.

18 Armstrong, A.; Li, W. N,N'-Carbonyldiimidazole in Encyclopedia of Reagents for Organic Synthesis, John Wiley \& Sons: Hoboken, 2007.

19 Anslyn, E. V.; Dougherty, D. A. "Chapter 2: Strain and Stability.” Modern Physical Organic Chemistry; University Science: Sausalito, CA, 2006; 100-109.

20 pKa values calculated by ACD 
21 Gleeson, M.P. J. Med. Chem. 2008, 51, 817-834.

22 Mukherjee, S.; Pal, M. Curr. Med. Chem. 2013, 20, 4386-4410 and references cited therein.

23 Carpino, L. A. J. Am. Chem. Soc. 1993, 115, 4397-4398.

24 Evans, D. A.; Bartroli, J.; Shih, T. L. J. Am. Chem. Soc. 1981, 103, 2127-2129.

25 Mullen, G.; Napier, J.; Balestra, M.; DeCory, T.; Hale, G.; Macor, J.; Mack, R.; Loch, J.; Wu, E.; Kover, A.; Verhoest, P.; Sampognaro, A.; Phillips, E.; Zhu, Y.; Murray, R.; Griffith, R.; Blosser, J.; Gurley, D.; Machulskis, A.; Zongrone, J.; Rosen, A.; Gordon, J. J. Med. Chem. 2000, 43, 4045-4050.

26 Gage, J. R.; Evans, D. A. Org. Synth. 1990, 68, 77-80.

27 Armarego, W. L. F.; Chai, C. L. L. Purification of Laboratory Chemicals, 6th Ed., Elsevier Inc., Oxford, UK, 2009.

28 Heller, S. T.; Fu, T.; Sarpong, R. Org. Lett. 2012, 14, 1970-1973.

29 Movassaghi, M.; Schmidt, M. A. Org. Lett. 2005, 7, 2453-2456.

30 Shen, B.; Makley, D. M.; Johnston, J. N. Nature, 2010, 465, 1027-1033.

31 Mahe, O.; Desroches, J.; Paquin, J.-F. Eur. J. Org. Chem. 2013, 4325-4331.

32 De Sarkar, S.; Grimme, S.; Studer, A. J. Am. Chem. Soc. 2010, 132, 1190-1191.

33 Gu, K.; Bi, L.; Zhao, M.; Wang, C.; Ju, J.; Peng, S. Bioorg. Med. Chem. 2007, 15, 4775-4799.

34 Pridgen, L. N.; Prol, Jr., J. J. Org. Chem. 1989, 54, 3231-3233

35 Gabriele, B.; Salerno, G.; Brindisi, D.; Costa, M.; Chiusoli, G. P. Org. Lett. 2000, 2, 625-627.

36 Xiong, H.; Grebe, T. M. R.; Mulder, J. A.; Hsung, R. P. Org. Synth. 2005, 81, 147-156

37 Adams, H.; Collins, R. C.; Jones, S.; Warner, C. J. A. Org. Lett. 2011, 13, 6576-6579.

38 Imada, Y.; Mitsue, Y.; Ike, K.; Washizuka, K.-I.; Murahashi, S.-I. Bull. Chem. Soc. Jpn. 1996, 69, 2079-2090.

39 Donohoe, T. J.; Chughtai, M. J.; Klauber, D. J.; Griffin, D.; Campbell, A. D. J. Am. Chem. Soc. 2006, $128,2514-2515$. 